\title{
AN ADVANCED FUEL CELL SIMULATOR
}

\author{
A Thesis \\ by \\ PRABHA RAMCHANDRA ACHARYA
}

\begin{abstract}
Submitted to the Office of Graduate Studies of Texas A\&M University in partial fulfillment of the requirements for the degree of

MASTER OF SCIENCE
\end{abstract}

August 2004

Major Subject: Electrical Engineering 


\title{
AN ADVANCED FUEL CELL SIMULATOR
}

\author{
A Thesis \\ by \\ PRABHA RAMCHANDRA ACHARYA
}

Submitted to Texas A\&M University

in partial fulfillment of the requirements

for the degree of

MASTER OF SCIENCE

Approved as to style and content by:

\begin{tabular}{c}
\hline $\begin{array}{c}\text { Prasad Enjeti } \\
\text { (Chair of Committee) }\end{array}$ \\
\hline $\begin{array}{c}\text { Chanan Singh } \\
\text { (Member) }\end{array}$
\end{tabular}

Prabir Daripa

(Member)

\begin{tabular}{c}
\hline $\begin{array}{l}\text { Jo Howze } \\
\text { (Member) }\end{array}$ \\
\hline Chanan Singh \\
(Head of Department)
\end{tabular}

August 2004

Major Subject: Electrical Engineering 


\begin{abstract}
An Advanced Fuel Cell Simulator. (August 2004)

Prabha Ramchandra Acharya, B.E., College of Engineering, Pune, India

Chair of Advisory Committee: Dr. Prasad Enjeti
\end{abstract}

Fuel cell power generation systems provide a clean alternative to the conventional fossil fuel based systems. Fuel cell systems have a high efficiency and use easily available hydrocarbons like methane. Moreover, since the by-product is water, they have a very low environmental impact. The fuel cell system consists of several subsystems requiring a lot of effort from engineers in diverse areas. Fuel cell simulators can provide a convenient and economic alternative for testing the electrical subsystems such as converters and inverters.

This thesis proposes a low-cost and an easy-to-use fuel cell simulator using a programmable DC supply along with a control module written in LabVIEW. This simulator reproduces the electrical characteristics of a $5 \mathrm{~kW}$ solid oxide fuel cell (SOFC) stack under various operating conditions. The experimental results indicate that the proposed simulator closely matches the voltage-current characteristic of the SOFC system under varying load conditions. Effects of non-electrical parameters like hydrogen flow rate are also modeled and these parameters are taken as dynamic inputs from the user. The simulator is customizable through a graphical user interface and allows the user to model other types of fuel cells with the respective voltage-current data.

The simulator provides an inexpensive and accurate representation of a solid oxide fuel cell under steady state and transient conditions and can replace an actual fuel cell during testing of power conditioning equipment. 
To My Father 


\section{ACKNOWLEDGMENTS}

I am very grateful to my advisor and mentor Dr. Prasad Enjeti, who patiently guided me during my research work and provided invaluable technical inputs. I would like to thank Dr. Ira J. Pitel for practical insights into the industrial aspects of the research. Thanks to all my lab colleagues for their help and enthusiasm.

I would like to thank my family and friends for their encouragement and moral support. I would like to thank Anup for being there always. 


\section{TABLE OF CONTENTS}

CHAPTER

INTRODUCTION . . . . . . . . . . . . . . . . . . . . . . 1

A. Applications of Fuel Cells . . . . . . . . . . . . . . . 1

B. Working of a Typical Fuel Cell . . . . . . . . . . . . . . . . 2

C. Types of Fuel Cells . . . . . . . . . . . . . . . . . . . . . 4

D. Fuel Cell Power Plant . . . . . . . . . . . . . . . 4

E. Challenges in Fuel Cell Development . . . . . . . . . 5

F. Previous Work . . . . . . . . . . . . . . 6

G. Solar Array Simulators . . . . . . . . . . . . . . . . . 8

H. Battery Simulators . . . . . . . . . . . . . . . . . 14

I. Research Objective . . . . . . . . . . . . . . . . 16

J. Overview of Thesis . . . . . . . . . . . . . . 17

II FUEL CELL ELECTRICAL CHARACTERISTICS . . . . . . . 18

A. Energy Conversion Efficiency . . . . . . . . . . . . . 18

B. Efficiency and the Fuel Cell Voltage . . . . . . . . . . . 20

C. Fuel Cell Losses . . . . . . . . . . . . . . . . . . . . . . . . 20

D. Fuel Cell Performance Parameters . . . . . . . . . . . . . 23

1. Temperature ................. . . . 23

2. Pressure ..................... 24

3. Reactant Utilization and Gas Composition . . . . . 25

4. Current Density . . . . . . . . . . . . . 25

E. Fuel Cell Power Conditioning . . . . . . . . . . . 26

III FUEL CELL SIMULATOR MODEL AND ALGORITHM . . . 28

A. The Fuel Cell Blackbox . . . . . . . . . . . . . . . 28

B. Modeling the Fuel Cell Steady State Behavior . . . . . . . 28

C. Modeling the Fuel Cell Transient Behavior . . . . . . . . . 32

1. Sudden Increase in Load . . . . . . . . . . . . . . . . 32

2. Decrease in Hydrogen Flow Rate . . . . . . . . . . . 34

D. Fuel Cell Simulator Algorithm . . . . . . . . . . . . . . 35

IV IMPLEMENTATION OF THE SIMULATOR AND RESULTS . 37

A. Design Example . . . . . . . . . . . . . . . . 37 
CHAPTER

B. Components . . . . . . . . . . . . . . . . . 40

C. Working of the Fuel Cell Simulator . . . . . . . . . . . 44

D. Testing and Results . . . . . . . . . . . . . . 49

1. Steady State Mode. . . . . . . . . . . . . . 50

2. Transient Mode .............. . 51

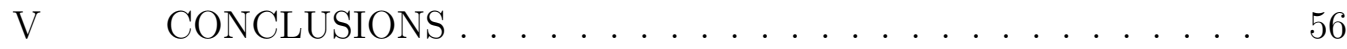

A. Future Improvements . . . . . . . . . . . . . . 57

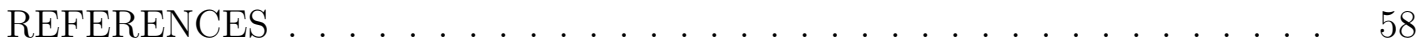

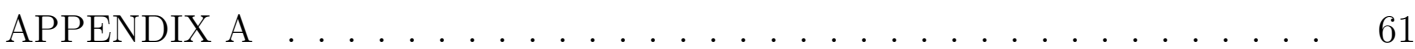

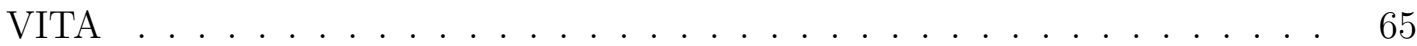




\section{LIST OF TABLES}

TABLE

Page

I Types of Fuel Cells . . . . . . . . . . . . . . . . . . . 4

II Maximum Reversible Cell Potentials $\mathrm{V}_{\text {rev }}$ and Maximum Efficiency Limit for Hydrogen Fuel Cells . . . . . . . . . . . . . . . . . . 19

III Experimental V-I Data for a $5 \mathrm{~kW}$ SOFC . . . . . . . . . . . . . 29

IV Configuration Settings for the Fuel Cell Simulator . . . . . . . . . . . 50

V Test Results for Steady State Operation . . . . . . . . . . . . 50

VI Test Results for Sudden Increase in Load . . . . . . . . . . . . . . . . 52

VII Test Results for Drop in Hydrogen Flow Rate . . . . . . . . . . . . . 54

VIII Test Results for Under-voltage Fault . . . . . . . . . . . . . . . 55 


\section{LIST OF FIGURES}

FIGURE

Page

$1 \quad$ Operation of a Fuel Cell . . . . . . . . . . . . . . . . . . 3

$2 \quad$ Fuel Cell Power Plant . . . . . . . . . . . . . . . . 6

3 A Simple Fuel Cell Simulator . . . . . . . . . . . . . . . . 7

$4 \quad$ Output Voltage and Power Loss vs Output Current . . . . . . . . . . 8

5 Block Diagram of the Photovoltaic Simulator . . . . . . . . . . 10

6 Power Circuit of the Photovoltaic Simulator . . . . . . . . . . . . . 11

$7 \quad$ Elgar's Solar Array Simulator . . . . . . . . . . . . . . . 12

8 Agilent's Solar Array Simulator . . . . . . . . . . . . . . . . . . 14

9 Block Diagram of the Battery Emulator . . . . . . . . . . . 15

$10 \quad$ Fuel Cell Electrical Characteristics . . . . . . . . . . . . . . . . 22

11 Effect of Temperature on Initial Operating Cell Voltage of Typical Fuel Cells ........................ 24

12 Fuel Cell Operating Point - Efficiency vs Cost . . . . . . . . . . 26

13 Power Conditioner for a Fuel Cell . . . . . . . . . . . . . . . 27

14 V-I Curve-fitting with Quadratic, Cubic and Fourth Order Polynomials . . . . . . . . . . . . . . . . . 30

15 Electrical Characteristics for a $5 \mathrm{~kW}$ SOFC Built by Fuel Cell Technologies, Ltd. . . . . . . . . . . . . . . 30

16 Convergence for Different Initial Guesses . . . . . . . . . . . . . . 33

17 Effect of Hydrogen Fuel Concentration on SOFC Voltage and Current Density . . . . . . . . . . . . . . . . . . . . 34 
18 Flowchart for the Fuel Cell Simulator . . . . . . . . . . . . . . . 36

19 Schematic of the Fuel Cell Simulator . . . . . . . . . . . . . . . . . 41

20 Components of the Fuel Cell Simulator . . . . . . . . . . . . . . . 43

21 Fuel Cell Simulator - Graphical User Interface . . . . . . . . . . . . . 45

22 Fuel Cell Simulator - Configuration Screen . . . . . . . . . . . . . . . 46

23 Fuel Cell Simulator - State Diagram . . . . . . . . . . . . . . . . 47

24 FCS Voltage and Current vs Time for Steady State Operation . . . . 51

25 FCS Voltage and Current vs Time for Sudden Increase in Load . . . 52

26 Effect of Slew Rate on the Simulator Voltage and Current . . . . . . 53

27 Effect of Decrease in Hydrogen Flow Rate on the Simulator Voltage and Current ..................... 54

$28 \quad$ Under-voltage Fault f . . . . . . . . . . . . . . . 55 


\section{CHAPTER I}

\section{INTRODUCTION}

The depleting fossil fuel resources and increasing pollution are leading to the research and development of alternate energy generation techniques like fuel cells and solar cells. Fuel cell systems have a high efficiency and use easily available hydrocarbons like methane thus alleviating the fuel shortage. Moreover, since the by-product is water, they have a very low environmental impact. The fuel cell system consists of several subsystems and a lot of effort in diverse areas is required to make it a popular choice for power generation.

An introduction is provided describing the working of the fuel cell, its applications and the challenges faced in making it a mainstream technology. Similar problems are faced in alternative technologies like solar cells and the solutions implemented are discussed. The objective of this master's thesis research is presented and the outline for the thesis is provided.

\section{A. Applications of Fuel Cells}

Fuel cells have been used extensively and successfully in spacecrafts and now efforts are on to commercialize the fuel cell. They have a wide range of applications which are listed below [1].

\section{Stationary power}

- Power generating stations

- Auxiliary units

The journal model is IEEE Transactions on Automatic Control. 
- Distributed power generation

- Residential use as combined heat and power (CHP) generation systems

2. Transportation

- Buses and cars

- Airport intra-terminal vehicles

3. Portable electronics

- Laptops

- Cellular phones

B. Working of a Typical Fuel Cell

Fuel cell is an electrochemical device that continuously converts the chemical energy of a fuel and oxidant into electrical energy and heat as long as the fuel and oxidant are supplied to the electrodes. A fuel cell is similar to a battery as it operates on the electrochemical energy conversion principle but there is an important difference; a fuel cell does not store fuel like a battery, but runs on a continuous supply of fuel. This makes it similar to engines, but unlike engines it does not combust the fuel giving out gases, it galvanically burns the fuel and the output is water. However, the efficiency of a heat engine is limited by the Carnot efficiency but since a fuel cell works on an electrochemical principle it is not similarly limited and thus can achieve a efficiency higher than a heat engine. Thus, a fuel cell achieves the continuous energy transformation from chemical to electrical form with very low pollution and high efficiency making it an excellent choice for power generation [1].

A fuel cell consists of a fuel electrode (anode) and an oxidant electrode (cathode), separated by an ion-conducting electrolyte as shown in Fig. 1. The electrodes are 


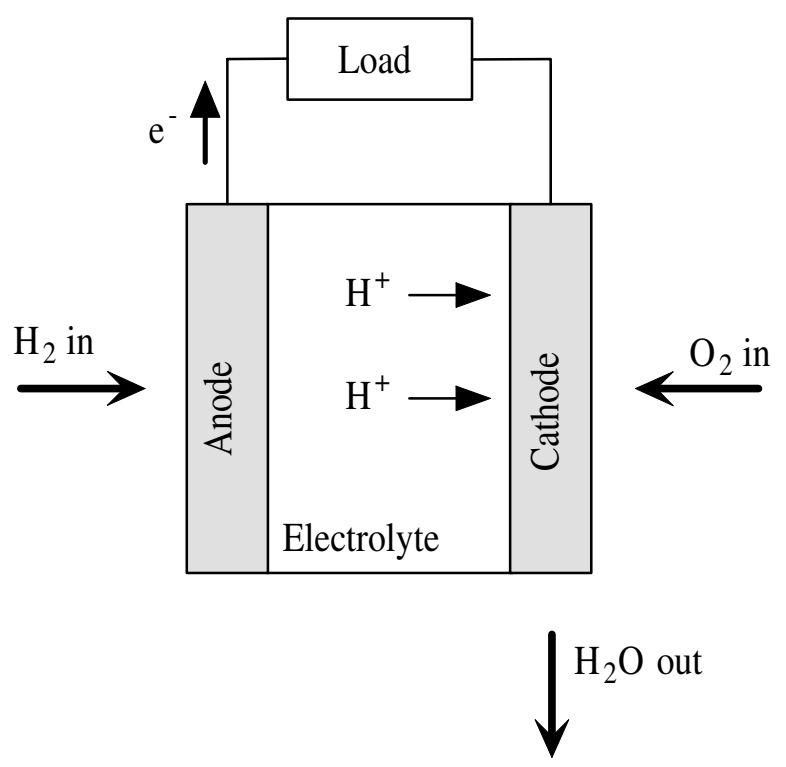

Fig. 1. Operation of a Fuel Cell

connected externally through a load, thus completing the electronic - ionic circuit. A basic fuel cell with hydrogen as the fuel and oxygen as the oxidant is considered. The hydrogen is ionized at the anode to give hydrogen ions and electrons. The electrolyte allows only the ionic flow and resists the electronic flow. Hence the electrons flow through the electrical circuit and reach the cathode after supplying power to the load whereas the hydrogen ions flow through the electrolyte to reach the cathode. Oxygen at the cathode reacts with the electrons and the hydrogen ions to form water. The overall reaction is the sum of the anodic and the cathodic reactions producing water. In high temperature fuel cells, the ionic carriers are carbonate ions for molten carbonate electrolyte fuel cells and oxide ions in the case of solid oxide fuel cells [2]. 


\section{Types of Fuel Cells}

Fuel cells are categorized based on the type of electrolyte used. Some of the popular fuel cells and their characteristics are listed in Table I [1].

Table I. Types of Fuel Cells

\begin{tabular}{|c|c|c|c|c|c|c|}
\hline $\begin{array}{l}\text { Fuel cell } \\
\text { type }\end{array}$ & Electrolyt & $\begin{array}{l}\text { Charge } \\
\text { car- } \\
\text { rier }\end{array}$ & $\begin{array}{l}\text { Operating } \\
\text { temp. }\end{array}$ & Fuel & $\begin{array}{l}\text { Electric } \\
\text { effi- } \\
\text { ciency }\end{array}$ & Application \\
\hline Alkaline FC & $\mathrm{KOH}$ & $\mathrm{OH}^{-}$ & $60^{\circ}-120^{\circ} \mathrm{C}$ & Pure $\mathrm{H}_{2}$ & $35-55 \%$ & $\begin{array}{l}<5 \mathrm{~kW} \text { mili- } \\
\text { tary, space }\end{array}$ \\
\hline $\begin{array}{l}\text { Proton } \\
\text { exchange } \\
\text { membrane } \\
\text { FC }\end{array}$ & $\begin{array}{l}\text { Solid poly- } \\
\text { mer }\end{array}$ & $\mathrm{H}^{+}$ & $50^{\circ}-100^{\circ} \mathrm{C}$ & $\begin{array}{l}\text { Pure } \mathrm{H}_{2}, \\
\text { tolerates } \\
\mathrm{CO}_{2}\end{array}$ & $35-45 \%$ & $\begin{array}{l}5 \text {-250kW } \\
\text { automotive, } \\
\text { portable } \\
\text { CHP }\end{array}$ \\
\hline $\begin{array}{l}\text { Phosphoric } \\
\text { acid FC }\end{array}$ & $\begin{array}{l}\text { Phosphoric } \\
\text { acid }\end{array}$ & $\mathrm{H}^{+}$ & $\sim 220^{\circ} \mathrm{C}$ & $\begin{array}{l}\text { Pure } \mathrm{H}_{2}, \\
\text { tolerates } \\
\mathrm{CO}_{2}\end{array}$ & $40 \%$ & 200kW CHP \\
\hline $\begin{array}{l}\text { Molten car- } \\
\text { bonate FC }\end{array}$ & $\begin{array}{l}\text { Lithium } \\
\text { and potas- } \\
\text { sium } \\
\text { carbonate }\end{array}$ & $\mathrm{CO}_{3}^{2-}$ & $\sim 650^{\circ} \mathrm{C}$ & $\begin{array}{l}\mathrm{H}_{2}, \quad \mathrm{CO}, \\
\mathrm{CH}_{4}, \\
\text { tolerates } \\
\mathrm{CO}_{2}\end{array}$ & $>50 \%$ & $\begin{array}{l}200 \mathrm{~kW}-\mathrm{MW} \\
\mathrm{CHP} \text { and } \\
\text { standalone }\end{array}$ \\
\hline $\begin{array}{l}\text { Solid oxide } \\
\text { FC }\end{array}$ & $\begin{array}{l}\text { Yttria, } \\
\text { Zirconia }\end{array}$ & $\mathrm{O}^{2-}$ & $\sim 1000^{\circ} \mathrm{C}$ & $\begin{array}{l}\mathrm{H}_{2}, \quad \mathrm{CO}, \\
\mathrm{CH}_{4}, \\
\text { tolerates } \\
\mathrm{CO}_{2}\end{array}$ & $>50 \%$ & $\begin{array}{l}2 \mathrm{~kW}-\mathrm{MW} \\
\mathrm{CHP} \text { and } \\
\text { standalone }\end{array}$ \\
\hline
\end{tabular}

\section{Fuel Cell Power Plant}

Since the fuel cell has a low environmental impact in terms of negligible air and noise pollution and requires low maintenance, it is an excellent choice for power generating systems and can also be placed in residential areas. A typical fuel cell power system shown in Fig. 2 consists of the following components [3]. 
1. Fuel processor: The fuel needs to be treated and purified before it can be used in the fuel cell. A fuel processor (also called a fuel reformer) is used to pretreat the fuel and boost the hydrogen concentration before it is fed into the fuel cell.

2. Fuel cell stack: This forms the heart of the fuel cell power system. A fuel cell stack is made up of individual fuel cells connected in series to increase the output DC voltage.

3. Power conditioner: The fuel cell output is a DC low voltage. Most applications use $\mathrm{AC}$ voltage. The power conditioner provides the interface between the fuel cell output and the load and thus regulates or converts the DC power to AC power. It also provides the control and grid interface.

4. Thermal and waste management: The heat and waste generated in the fuel cell and the fuel processor is dissipated or recovered (cogeneration) by the thermal and waste management system.

\section{E. Challenges in Fuel Cell Development}

Tremendous effort is being poured into making the fuel cell commercially viable. Each one of the four components of the fuel cell power plant described above plays an important role and contributes to the overall cost and efficiency of the power system. These components require efforts of engineers from diverse areas. Thermodynamic and electrochemical engineers are concerned with the development of the fuel cell, the fuel reformer and the thermal management system. The electrical engineers are responsible for the power conditioning equipment which bridges the gap between the fuel cell output and the specific demands of the load. Since there are several aspects of development occurring in parallel, if an accurate model of the fuel cell is built to 


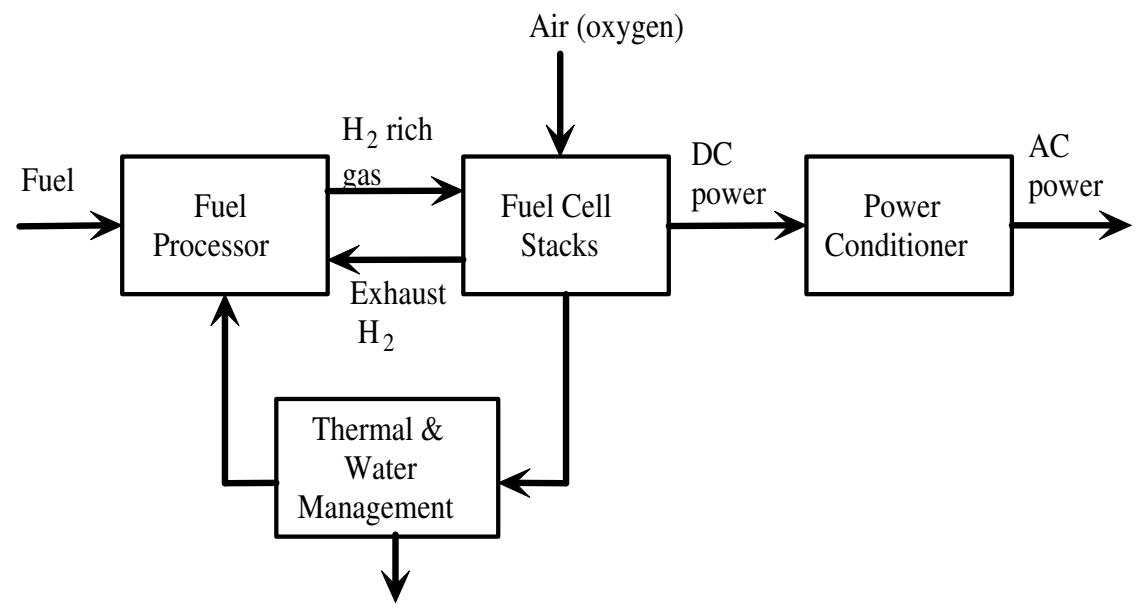

Excess heat \& water

Fig. 2. Fuel Cell Power Plant

simulate the behavior of the fuel cell it can greatly aid the development of the fuel cell technology, the control systems and the power electronics required for fuel cells.

\section{F. Previous Work}

In [4], [5] the transient behavior of a solid oxide fuel cell has been studied and simulated. Electrochemical and thermodynamic equations are used to model the processes in the fuel cell. The fuel cell model is simulated by a computer program, which accepts parameter values for input gas flows, fuel cell temperature etc., and outputs the terminal fuel cell voltage and current. In [6] a model based on a closed-form calculation of solid oxide fuel cell (SOFC) voltage for a given current, fuel and air compositions, and temperature has been implemented in a spreadsheet format. In [7] a mathematical model is used to describe the a proton exchange membrane (PEM) fuel cell and can be used to measure the stack performance. In all these simulation models, electrochemical and thermal equations are used to determine the polarization 
Simple fuel cell simulator

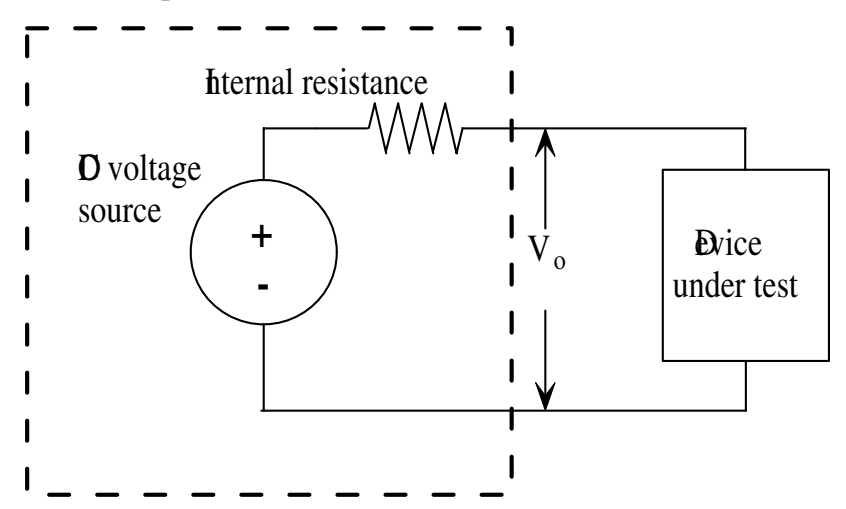

Fig. 3. A Simple Fuel Cell Simulator

losses and calculate the terminal voltage. The modeling of the fuel cell is done using computer programs but no actual hardware model is built.

The most common test-bench used by electrical engineers in place of a fuel cell is a DC power supply in series with a resistor representing the fuel cell internal resistance as shown in Fig. 3. This method makes a linear approximation of the output V-I curve of the fuel cell. Use of a resistor makes it a lossy approach and at high currents the loss in the resistor compares with the power output. For example, a $5 \mathrm{~kW}$ solid oxide fuel cell with a open-circuit voltage of $41 \mathrm{~V}$ and full load voltage of $22 \mathrm{~V}$ at a current of $275 \mathrm{~A}$ is represented by a DC power supply and a resistor. The variation of the output voltage $\left(\mathrm{V}_{o}\right)$ and power loss with current is shown in Fig. 4. The power loss in the resistor is very high and is almost equal to the rated output of fuel cell. Since, the power loss is in the form of heat, a cooling system might be required. Additionally, only steady state characteristic is modeled by the resistor, it can not replicate the transient behavior of a fuel cell.

A full power working model of the fuel cell would be greatly useful to an electrical 


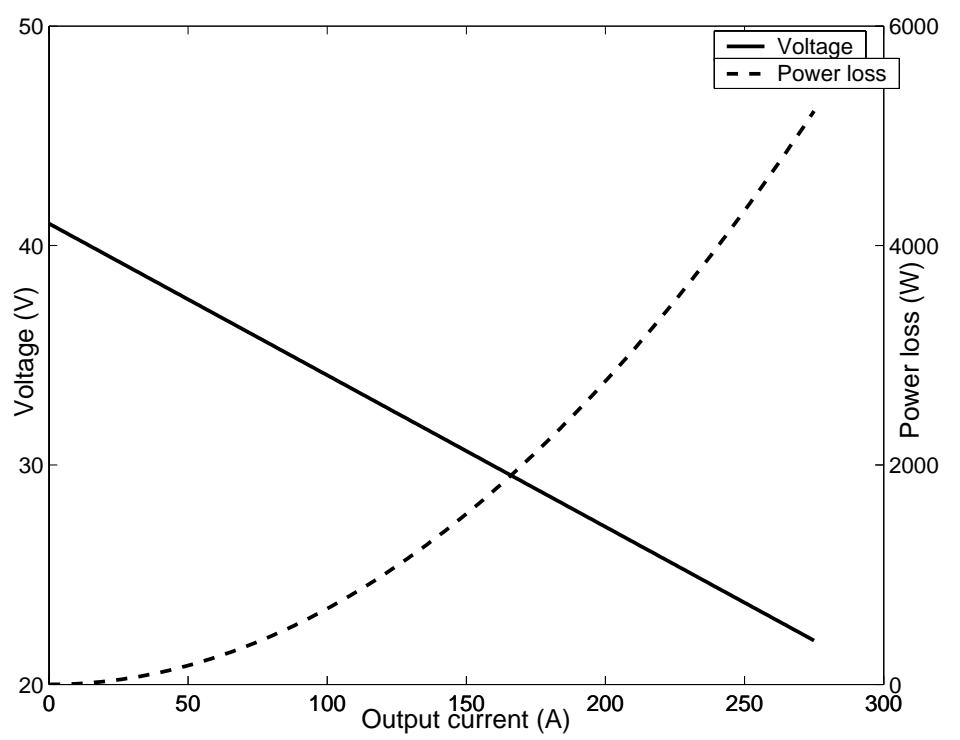

Fig. 4. Output Voltage and Power Loss vs Output Current

engineer who is dependent on the complete working of the fuel cell system to be able to test the power conditioning equipment. Parallel development of the fuel cell technology and power conditioning equipment can be helped by the presence of a fuel cell simulator that would replicate the fuel cell behavior at a fraction of the current fuel cell cost. Similar problems are faced in other power generation systems like solar cells, batteries and simulators have been built to ease the development and testing of power electronics.

\section{G. Solar Array Simulators}

Solar cells (also called photovoltaic cells), like fuel cells, pose challenges to the electrical engineer who has to develop specialized power conditioning equipment so as to make the solar cell usable commercially. The solar cells are made up of a material 
that directly converts the solar energy into DC electricity. Since the solar cells are totally dependent on the availability and quality of the sunlight, their output varies with changes in the incident sunlight. These variations in the solar cell output need to be compensated by a energy storage device like a battery so that the load does not suffer. Thus a power electronics interface is required to regulate the output. For widespread use, the low DC voltage has to be stepped up and inverted to the popular $110 \mathrm{~V}$ AC.

It is expensive to invest in high power photovoltaic modules for testing the power electronic converters. Also it is impossible to demand varying solar conditions that are required to test the power electronics system. Photovoltaic simulators that emulate the electrical characteristics of a photovoltaic cell have been built to address this problem [8], [9]. The effect of varying incident light on the photovoltaic cell is modeled and is provided as a user controlled parameter. The simulators can replace the photovoltaic cells in the test environment for the power electronic converters.

The photovoltaic simulator developed by Zeng et al., emulates the output characteristics of photovoltaic modules and thus can replace the actual photovoltaic modules [8]. It consists of a bridge rectifier, DC chopper and a control system based on the 80C196KC microprocessor as shown in Fig. 5.

The power conversion is performed by a three phase bridge rectifier and a DC chopper. The power circuit is shown in Fig. 6. The 3-phase bridge rectifier converts the AC source input to unregulated DC voltage provided as input to the DC chopper. The DC chopper is designed as a typical step-down or buck chopper. An IGBT is chosen as the switching component $\mathrm{T}_{1}$. The duty cycle of the pulse width modulation (PWM) waveform is controlled by the control system so that output of the DC chopper matches the photovoltaic module I-V curve. The control system shown in Fig. 5 consists of an interface board, a 80C196KC microprocessor, a PWM generator and 


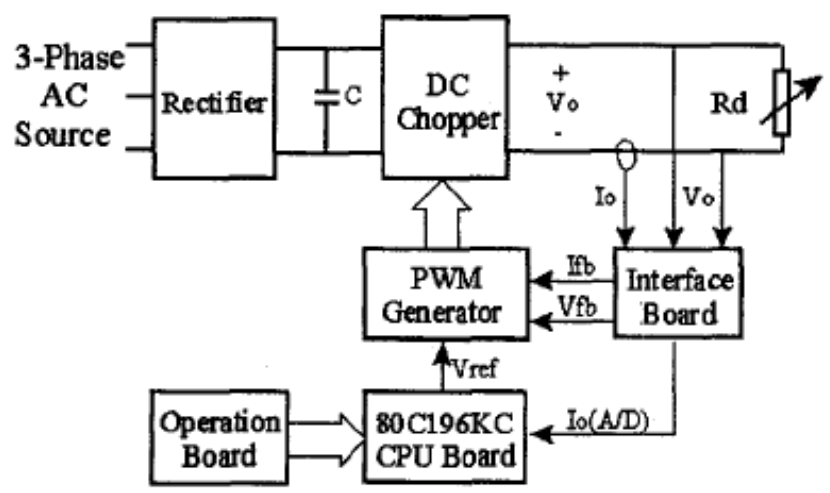

Fig. 5. Block Diagram of the Photovoltaic Simulator

an operation board. The interface board isolates and filters the output of the current and voltage transducers. The instantaneous current and voltage is sent to the PWM generator and the average value of current is fed to the $80 \mathrm{C} 196 \mathrm{KC}$ microprocessor. Photovoltaic module I-V data tables are stored in the 80C196KC microprocessor, which calculates the reference voltage based on the feedback information, and sends it to the PWM generator. The PWM generator adjusts the duty cycle of the PWM such that the feedback voltage tracks the reference voltage. The operation board provides a interface to accept user defined parameters such as number of modules and solar insolation. The simulator provides the flexibility and convenience to the electrical engineer for testing various conditions in the laboratory itself without having to invest in actual solar cells or working outdoors for testing various solar conditions.

Elgar Electronics Corporation has developed a solar array simulator that reproduces various solar array outputs, based on the wide variety of input conditions that an array faces, including orbital rotation, spin, axis alignment, eclipse events, 


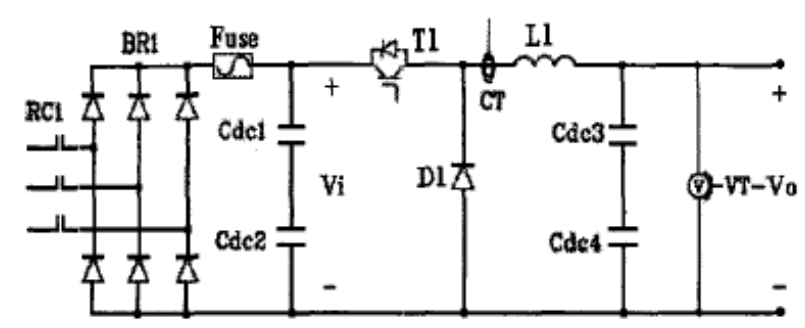

Fig. 6. Power Circuit of the Photovoltaic Simulator

beginning-of-life and end-of-life operation and is shown in Fig. 7 [10]. It provides complete programmable control of all the parameters that shape the solar cell $\mathrm{I} / \mathrm{V}$ output curve. The solar array simulator is made up of Elgar's Fast Profiling Current Source (FPCS) modules that can be connected in series or parallel depending on the application power requirements. An embedded Motorola microprocessor in each FPCS module provides the computational power necessary to calculate the output transfer function, to communicate via a fiber optic data link to the system computer and to continuously monitor the state of the power sections. The FPCS is designed to operate continuously at the peak power output, or the knee, of the solar array output. The I/V curve is controlled by the following four parameters.

1. Maximum programmed open circuit voltage at no load $\left(\mathrm{V}_{o c}\right)$

2. Maximum programmed short circuit current operating into short $\left(\mathrm{I}_{s c}\right)$

3. Maximum programmed effective series resistance $\left(\mathrm{R}_{s}\right)$

4. Curve factor $(\mathrm{N})$ 


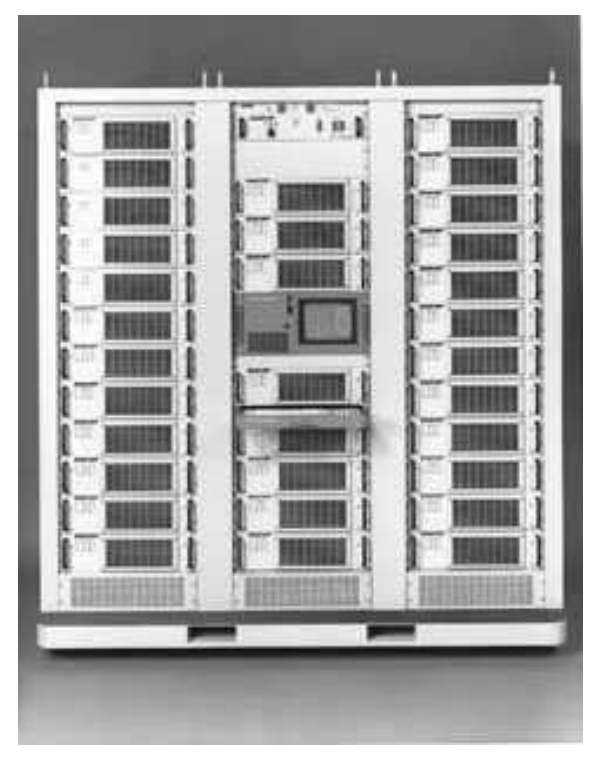

Fig. 7. Elgar's Solar Array Simulator

The solar array simulator has a Windows NT graphical user interface and hardware control software. It can be controlled remotely and integrated into a customer's test system via a standard ethernet or optional GPIB interface using standard SCPI format commands. By being able to accurately simulate solar panels under various space conditions with complete control, a system developer can comprehensively verify design margins and quickly test, in production, spacecraft power systems and their associated electronics [10].

The solar array simulator from Agilent Technologies is a DC power source that simulates the output characteristics of a solar array [11]. It is primarily a current source with very low output capacitance and is capable of simulating the I-V curve of different arrays under different conditions (e.g., temperature, age). The I-V characteristic for the simulator in various modes of operation is shown in Fig. 8. The 
I-V curve is programmable over the IEEE-488.2 bus. The simulator provides three current operating modes.

1. Simulator mode: An internal algorithm is used to approximate a solar array I-V curve. Four input parameters: Voc (open circuit voltage), Isc (short circuit current), Imp and Vmp (current and voltage at the peak power point on the curve) are needed to establish a curve in this mode.

2. Table mode: For a fast and accurate I-V simulation, the simulator provides a table mode. The I-V curve is set by a user-defined table of points. A table can have any length up to 4000 points (a point corresponds to a specific value of $\mathrm{I}$ and V). As many as 30 tables may be stored in each of the simulators built-in volatile and non-volatile memory using an IEEE-488.2 command. In Table Mode, current and voltage offsets can be applied to the selected table to simulate a change in the operating conditions of the solar array.

3. Fixed mode: This is the default mode when the unit is powered on. The unit has the rectangular I-V characteristics of a standard power supply, when an output capacitor is added in this mode.

The solar array simulator built by Spectra-Nova Technologies, Inc. emulates the power generation of a solar array in diverse operating conditions. This capability combined with their fast transient response, makes it possible to power a photovoltaic application device in exactly the same way as a solar array will power it during its actual use. The software has a large data base storing the actual characteristics of the solar modules (crystalline and thin films) made by the major manufacturers around the world. They can be used in series/parallel combinations to generate a desired configuration of an array. The user can vary external conditions such as light intensities, 

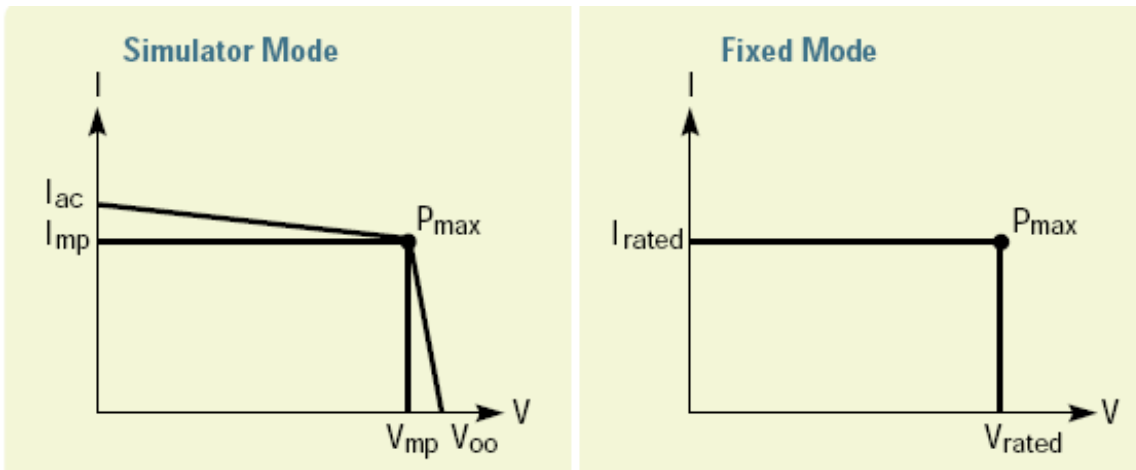

Fig. 8. Agilent's Solar Array Simulator

temperature,and tilting of the solar panel. A hybrid system of photovoltaic-windDiesel based on random, daily or seasonal combinations can also be simulated. The array simulator becomes an invaluable tool in designing and prototyping new solar applications and devices without the expenses and uncertainties related to using a real solar array [12].

\section{H. Battery Simulators}

Typically the current drawn from a battery is constant. But studies show that pulsed current can extend the life of a battery. New power management techniques that exploit non-ideal features of batteries in order to maximize their effective lifetime are being developed. To validate these power management techniques, researchers can use either real batteries or battery simulators. If non-rechargeable batteries are used, then they must be replaced and disposed of after each experiment, making this approach expensive and unfriendly to the environment. Rechargeable batteries produce less waste and but the results may not be very reproducible, because the discharge and 


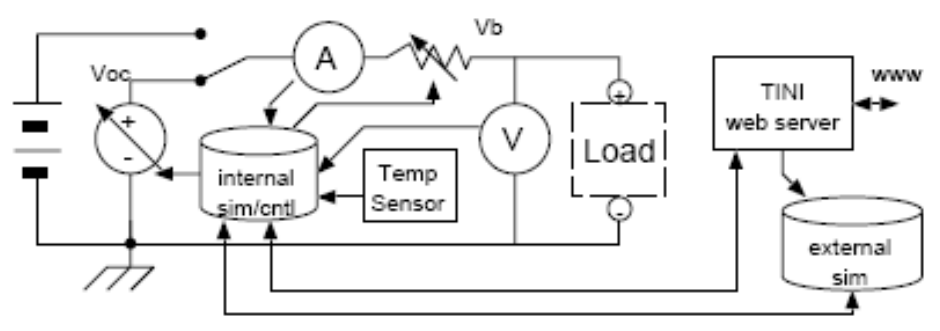

Fig. 9. Block Diagram of the Battery Emulator

recharge history of the battery and the battery age will affect the total charge level each time. In [13], Chou et al., have built a battery emulator using a programmable power supply that mimics the battery characteristic. It consists of the power circuit, measurement circuit and digital subsystem. The power circuit comprises of a 10 bit data acquisition card (DAC) and an adjustable linear regulator which operates between $1 \mathrm{~V}$ and $4.5 \mathrm{~V}$. The DAC provides the interface between the microcontroller and the linear adjustable regulator. The simulator contains measurement circuits for reading current, temperature, and voltage. The digital subsystem consists of the PIC16F877 microcontroller, an RS-232 serial port, an Ethernet port, and an optional USB port to communicate with a host computer. The PIC16F877 microcontroller has eight built-in (analog to digital) ADC channels and a UART for serial communication. Fig. 9 shows the block diagram of the simulator. The feedback information read from the measurement circuits is provided to the microcontroller which computes the battery simulator voltage which is sent to the linear regulator. The microcontroller has limited memory and hence a simplified model resembling a Mealy machine with 256 charge states is used. For elaborate simulation based on the chemical reactions 
inside the battery, the simulator can be controlled externally from a computer through the RS-232 port or the ethernet port.

\section{Research Objective}

The objective of the thesis is to design and implement a low-cost fuel cell simulator that can replicate the behavior of a fuel cell under a wide range of steady state and transient conditions. The simulator will provide an advanced test environment to verify power conditioning devices designed for fuel cells. A blackbox approach is adopted for modeling and hence the complicated electrochemical and thermal equations are avoided. A mathematical model is developed and the fuel cell is treated as a DC power source with a non-linear internal resistance. Actual fuel cell polarization curves for various operating conditions are studied and mathematical techniques such as polynomial curve fitting are used to model non-linear voltage current characteristic of the fuel cell. A computer running a LabVIEW program controls and commands a programmable power supply thereby emulating the fuel cell behavior. The simulator can be configured with the experimental data to replicate various types of fuel cells.

The research focuses on a SOFC simulator since it shows a lot of promise in the area of stationary power generation. The US Department of Energy conducted the Future energy challenge 2003 competition with stringent specifications for development of an inverter for a 5kW SOFC developed by Fuel Cell Technologies, Ltd. The electrical characteristics for the $5 \mathrm{~kW}$ SOFC were studied and replicated in this thesis.

The fuel cell simulator developed was used in the competition in place of the actual SOFC to test and judge the inverters. 


\section{J. Overview of Thesis}

Chapter I provides an introduction to the fuel cell technology, discusses the need for simulation, prior work done in the area and the research objective of the thesis.

Chapter II discusses the fuel cell thermodynamic and electrochemical equations. It explains the losses occurring in the fuel cell and the polarization curves under various conditions. The various parameters affecting the fuel cell behavior are presented.

Chapter III details the SOFC electrical characteristics. The modeling approach adopted to design the simulator is presented. The mathematical equations describing the simulator model, the algorithm and the control strategy used to emulate the fuel cell are explained.

Chapter IV is devoted to the explanation of the setup of the hardware for the fuel cell simulator. The interaction between the various components and the software and hardware are explained. The working of the fuel cell simulator and the results are presented.

Chapter V presents the conclusions and suggests further improvements. 


\section{CHAPTER II}

\section{FUEL CELL ELECTRICAL CHARACTERISTICS}

In order to design a simulator, a mathematical model of the fuel cell needs to be developed. The internal working of the fuel cell needs to be studied and the effects of various parameters need to be known. In this chapter, the electrochemical and thermodynamic principles of fuel cells are described and the effect of various parameters such as temperature, pressure and reactant composition on the fuel cell power output are studied.

\section{A. Energy Conversion Efficiency}

Since a fuel cell burns the fuel galvanically the enthalpy change $(\Delta H)$ during combustion is not converted entirely to heat. Instead of hot molecules in random motion, a stream of electrons is given out whose maximum total energy is equal to the change in free energy (also called Gibbs energy, $\Delta G$ ) for the reaction. In an ideal fuel cell, all the free energy change is available in the form of electrical energy. The efficiency of the energy conversion is based on energy output produced relative to change in thermal energy between reactants and products given by the enthalpy change for the process. Thus the maximum energy conversion efficiency $\left(\eta_{\max , e c}\right)$ of a fuel cell is given by $(2.1)$

$$
\eta_{\text {max }, e c}=\frac{\Delta G_{T}}{\Delta H_{o}}
$$

where $\Delta G_{T}$ is the Gibbs energy at cell operating temperature $\mathrm{T}$ and $\Delta H_{o}$ is the thermal energy at the standard temperature $(298.15 \mathrm{~K})$ and pressure $(100 \mathrm{kPa})(\mathrm{STP})[2]$. It is important to note that for fuels containing hydrogen the value for thermal $\operatorname{energy}(\Delta H)$ varies depending on whether the output is liquid water or vapor. The 
Table II. Maximum Reversible Cell Potentials $\mathrm{V}_{\text {rev }}$ and Maximum Efficiency Limit for Hydrogen Fuel Cells

\begin{tabular}{|l|r|r|r|}
\hline $\begin{array}{l}\text { Form of water } \\
\text { product }\end{array}$ & $\begin{array}{r}\text { Temp } \\
\left({ }^{\circ} \mathbf{C}\right)\end{array}$ & $\begin{array}{r}\text { Max V } \\
\text { rev } \\
(\mathbf{V})\end{array}$ & $\begin{array}{r}\text { Efficiency } \\
\text { limit (\%) }\end{array}$ \\
\hline Liquid & 25 & 1.23 & 83 \\
Liquid & 80 & 1.18 & 80 \\
Gas & 100 & 1.17 & 79 \\
Gas & 200 & 1.14 & 77 \\
Gas & 400 & 1.09 & 74 \\
Gas & 600 & 1.04 & 70 \\
Gas & 800 & 0.98 & 66 \\
Gas & 1000 & 0.92 & 62 \\
\hline
\end{tabular}

two values are called the higher heating value (HHV) and the lower heating value (LHV) respectively and the latent heat of vaporization accounts for this difference.

The maximum efficient limit and maximum reversible open circuit voltage for a hydrogen fuel cell for various temperatures is described in Table II [14]. It appears from the ideal case that low temperature fuel cells have higher efficiency and voltages, however, in actual fuel cells the losses are higher at low temperatures as compared to losses at high temperatures. The high temperature fuel cells can be used in combined heat and power (CHP) systems and show a higher system efficiency. For non-hydrogen fuel cells the relation between temperature and efficiency may not be the same. For the reaction $\mathrm{CO}+\frac{1}{2} \mathrm{O}_{2} \rightarrow \mathrm{CO}_{2}$ the maximum efficiency drops from $82 \%$ at $100^{\circ} \mathrm{C}$ to $52 \%$ at $1000^{\circ} \mathrm{C}$. However, for the reaction, $\mathrm{CH}_{4}+2 \mathrm{O}_{2} \rightarrow \mathrm{CO}_{2}+2 \mathrm{H}_{2} \mathrm{O}$, the maximum efficiency hardly varies with temperature. 


\section{B. Efficiency and the Fuel Cell Voltage}

From Table II, it is seen that there is a connection between the maximum efficiency and the maximum voltage. For a hydrogen fuel cell, the thermal energy of the reaction $(\Delta H)$ is $285.8 \mathrm{~kJ} /$ mole and the Gibbs free energy $(\Delta G)$ is $237.1 \mathrm{~kJ} / \mathrm{mole}$. From 2.1 it follows the maximum thermal efficiency at STP is 0.83. Using the LHV for hydrogen, the ideal voltage is $1.229 \mathrm{~V}$ for hydrogen fuel cell operating reversibly at STP. The actual efficiency of a fuel cell can be expressed as a ratio of the actual fuel cell voltage to the ideal voltage as follows [15].

$$
\begin{aligned}
\eta & =\frac{\text { UsefulEnergy }}{\Delta H} \\
\text { i.e. } \eta & =\frac{U \text { sefulPower }}{\Delta G \div 0.83} \\
\text { i.e. } \eta & =\frac{V_{\text {cell }} \times \text { current }}{V_{\text {rev }} \times \text { current } \div 0.83} \\
\text { i.e. } \eta & =\frac{0.83 \times V_{\text {cell }}}{V_{\text {rev }}} \\
\text { i.e. } \eta & =\frac{0.83 \times V_{\text {cell }}}{1.229} \\
\text { i.e. } \eta & =0.675 \times V_{\text {cell }}
\end{aligned}
$$

where $V_{\text {cell }}$ is the actual fuel cell terminal voltage and $V_{\text {rev }}$ is the ideal voltage.

\section{Fuel Cell Losses}

An actual fuel cell has a lower efficiency than the ideal one because of the irreversible losses in the cell reaction. The fuel cell terminal voltage drops from the open circuit voltage and this drop in voltage is proportional to the current drawn by the electric circuit. This phenomenon is known as polarization. There are three main types of polarization: activation polarization, ohmic polarization and concentration polarization. 
1. Activation polarization: This occurs due to slow charge transfer reaction at the surface of the electrodes. Some of the electrode potential is used to drive the electron transfer to match the current demand and thus the potential at the fuel cell terminal is reduced. Activation polarization depends on the nature of type of electrode, ionic interactions, ion-solvent interactions and the electrodeelectrolyte interface. Increase in temperature reduces the loss due to activation polarization. Using a catalyst to speed up the charge transfer and increasing the active surface area of the electrode improves the cell performance.

2. Ohmic polarization: This occurs due to resistance to the flow of ions in the electrolyte, resistance to the flow of electrons through the electrodes and the contact resistance at the cell terminals. These losses can be reduced by using electrolytes with high ionic conductivity, electrodes with high electronic conductivity and reducing the space between electrodes to minimize electrolyte resistance.

3. Concentration polarization: This occurs due to a decrease in the concentration of the reactants at the electrode-electrolyte interface. A steady supply of the reactants is required at the electrode-electrolyte interface to maintain the flow of electric current. Due to diffusion or convection problems in the electrolyte, the concentration of the reactants is not maintained at the initial level. Reaction product accumulation can also cause dilution of reactants. The concentration gradient thus formed, causes a drop in electrode activity and the terminal voltage is reduced.

The ideal and the practical fuel cell electric characteristics are shown in Fig. 10 [14]. In a practical fuel cell, the voltage drop is significantly more at low and high current densities. At low current densities, the activation polarization is predominant 


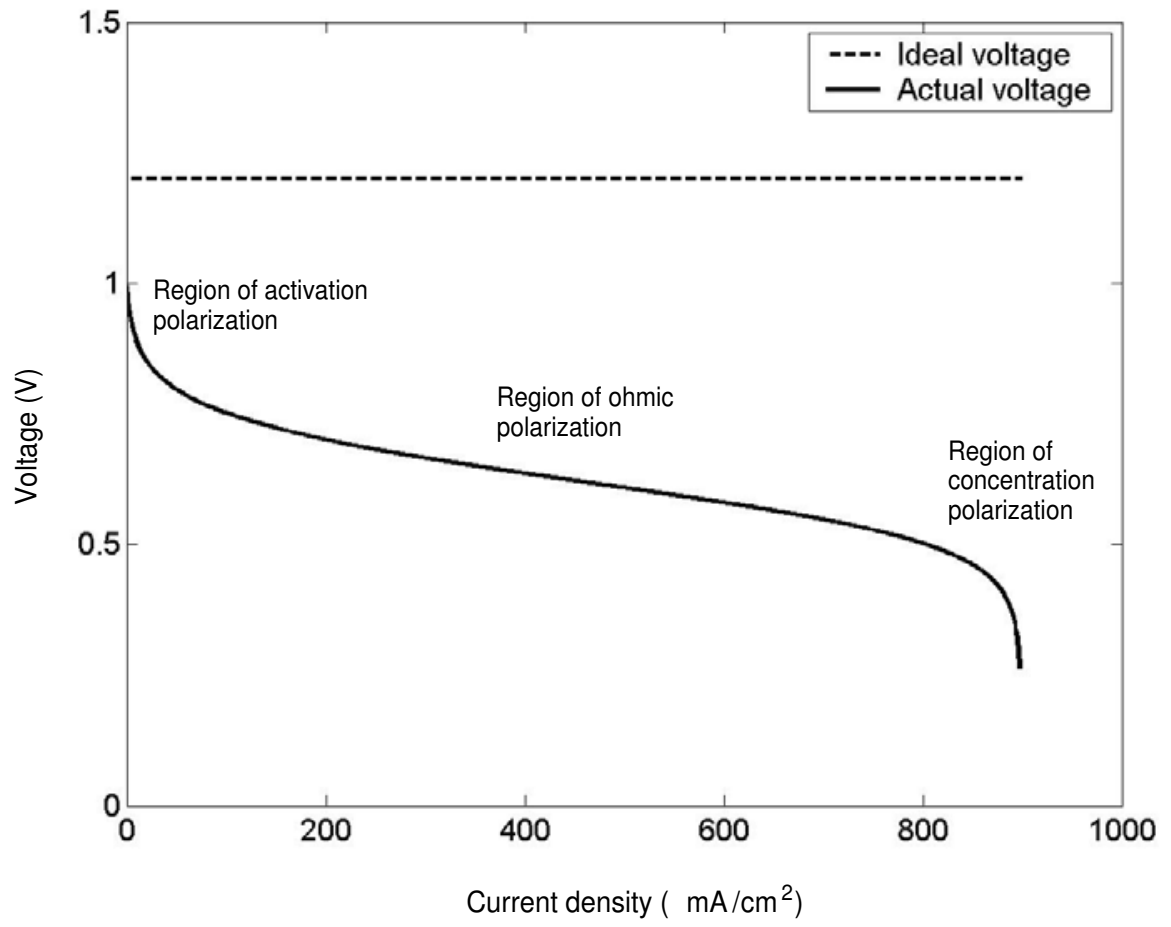

Fig. 10. Fuel Cell Electrical Characteristics

and at high current densities, the concentration polarization is a major cause of losses. The ohmic polarization is nothing but cell resistance and hence with increase in cell current the voltage drop increases proportionately. Low temperature fuel cells exhibit high activation polarization at low current densities. On the other hand, high temperature fuel cells have a low activation losses and ohmic polarization is the most important cause for losses. 


\section{Fuel Cell Performance Parameters}

Fuel cell performance is affected by design parameters such as cell size, power level, cost and by operating variables such as temperature, pressure, fuel composition and current density. Many of these parameters have opposing influences and a compromise has to be arrived at based on constraints dictated by the application.

\section{Temperature}

From Table II, it is seen that with increase in temperature the reversible voltage for a hydrogen fuel cell decreases. But for an actual fuel cell the effect of temperature is different and is shown in Fig. 11 [15]. The cell voltages of PEFCs, PAFCs, and MCFCs show a strong, positive dependence on temperature. PEFCs show increase in voltage till a point and suddenly the voltage drops with further increase in temperature. This is due to water management problems at temperatures above $100^{\circ} \mathrm{C}$. SOFCs are operated at about $1000^{\circ} \mathrm{C}$ because the ohmic resistance of the electrolyte increases rapidly with decrease in temperature. The improvement in performance at higher temperatures is due to decrease in polarization losses. An increase in temperature leads to an increase in reaction rate, higher mass transfer rate and lower cell resistance due to improved ionic conductivity of the electrolyte. For low-temperature fuel cells the $\mathrm{CO}$ tolerance of electrolytes increases with rise in temperature. However, material problems related to corrosion, electrode degradation, electrocatalyst sintering and recrystallization and electrolyte loss due to evaporation are accelerated at higher temperatures [15]. 


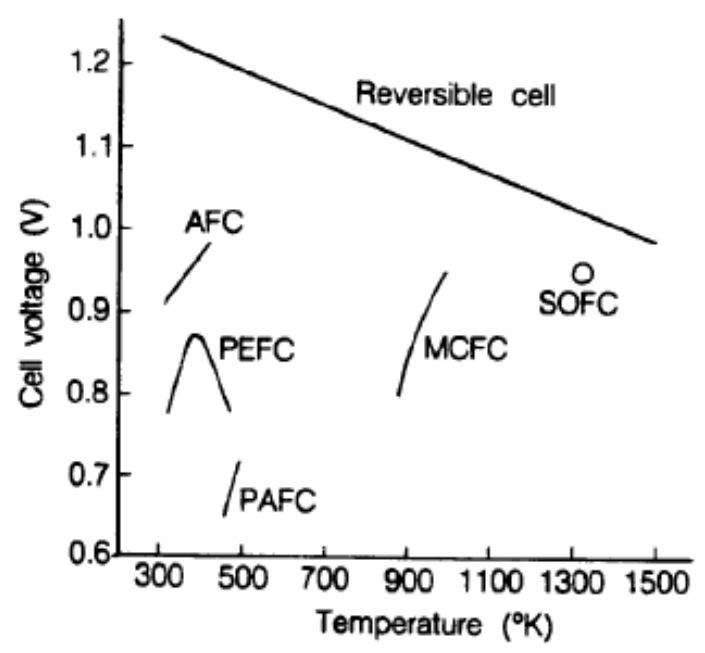

Fig. 11. Effect of Temperature on Initial Operating Cell Voltage of Typical Fuel Cells

\section{Pressure}

The change in Gibbs free energy due to pressure can be studied by the Nernst equation [14]. It shows the effect of pressure on cell voltage as follows.

$$
E=E^{0}+\frac{R T}{2 F} \ln \left(\frac{\alpha \cdot \beta^{\frac{1}{2}}}{\delta} \cdot P^{\frac{1}{2}}\right)
$$

where $E^{0}$ is the EMF at standard pressure $(100 \mathrm{kPa}), \mathrm{F}$ is the Faraday constant (96485 C), $\alpha, \beta$ are constants depending on molar masses and concentrations of the reactants, $\delta$ is a constant depending on molar mass and concentrations of the product, and $\mathrm{P}$ is the system pressure. The pressure on both the cathode and anode are assumed same to simplify the equation.

From (2.3), it is seen that increasing the operating pressure of the fuel cell has a positive impact on the cell voltage. Increase in pressure implies that the reactant 
partial pressure, gas solubility and mass transfer rates are higher. Additionally, electrolyte loss by evaporation is lower at a high pressure. But this is offset by the extra power required to compress the reactants and the financial cost required to improve the structural strength of the fuel cell to withstand the higher pressure.

\section{Reactant Utilization and Gas Composition}

As the fuel and the oxidant pass through the fuel cell and react at the electrodes, their partial pressures decrease and the reaction products increase causing the cell potential to fall. The voltage varies throughout the cell and is at the lowest near the fuel outlet where the fuel concentration is lowest. In case of fuel cell stacks with bipolar electrodes, the voltage cannot change along the electrode and thus the current density drops near the exit where the fuel concentration is lower. Thus low fuel utilization leads to a higher cell voltage. However, for a high system efficiency, the fuel utilization should be high. These two contrasting factors need to be optimized so that both cell voltage and system efficiency are balanced [14].

From (2.3), it is seen that increase in fuel partial pressure leads to an increased cell voltage. Changing the gas composition from 100\% hydrogen to $50 \%$ hydrogen combined with carbon dioxide in a PAFC will reduce the voltage by $0.015 \mathrm{~V}$ per cell.

\section{Current Density}

The fuel cell efficiency can be improved by operating the fuel cell at a higher voltage, but this results in low current density and low power density. To increase the power output, the cell area has to be increased resulting in a larger, heavier and costlier fuel cell. Fig. 12 shows the relation between fuel cell voltage, current density and power density [15]. The fuel cell efficiency conflicts with the size and the cost of fuel cell and an optimal operating point for the fuel cell has to be chosen based on application 


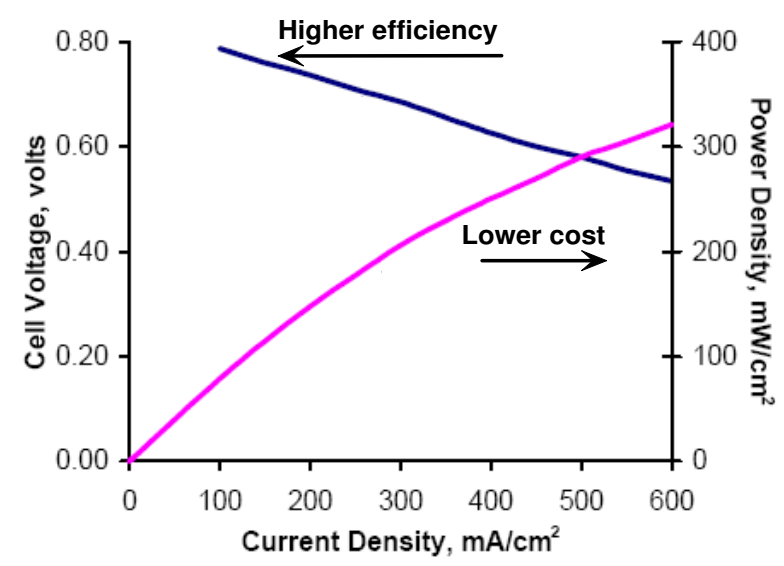

Fig. 12. Fuel Cell Operating Point - Efficiency vs Cost

requirements.

E. Fuel Cell Power Conditioning

The fuel cell power system has specific power conditioning requirements:

1. Regulation: The voltage from all sources of electrical power varies with time, temperature, pressure, and other factors and most importantly load current. However, fuel cells are particularly badly regulated. From Fig. 10, it can be seen that when all other factors are constant, the actual fuel cell shows a marked voltage drop with increase in current density. Most electrical equipment work with a constant voltage with slight variation. A regulator using switching or chopping circuits is required to maintain a constant DC output voltage.

2. DC to AC conversion: The fuel cell outputs low DC voltage. However, for 


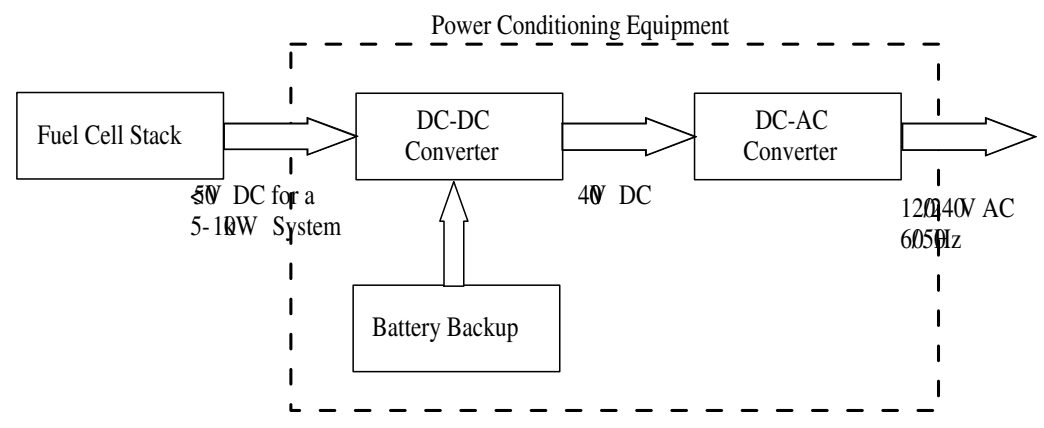

Fig. 13. Power Conditioner for a Fuel Cell

stationary power generation, AC output is preferred. Hence a converter would be required to boost the $\mathrm{DC}$ voltage and an inverter to convert $\mathrm{DC}$ to $\mathrm{AC}$ voltage.

3. Battery backup: A fuel cell responds slowly to change in power demand. To meet the load fluctuations, a battery or a similar energy storage device is used.

Fig. 13 shows the components of the power conditioning unit for a fuel cell. A DC-DC converter regulates and steps up the DC voltage to $400 \mathrm{~V}$ DC. In case of sudden load demand, the DC-DC converter draws the extra power from a battery and during low loads, the battery is recharged. The DC-DC converter output forms the input to the DC-AC inverter, which produces an AC output voltage of $120 / 240 \mathrm{~V}$ at $60 / 50 \mathrm{~Hz}$.

A fuel cell simulator that can emulate the fuel cell under various conditions provides an inexpensive and easy-to-use platform to test the power conditioning devices. In the next chapter, the mathematical model of the simulator is described. 


\section{CHAPTER III}

\section{FUEL CELL SIMULATOR MODEL AND ALGORITHM}

In this chapter, the mathematical basis used for modeling the fuel cell is presented. A blackbox approach has been adopted and thus the simulator developed can be generalized to represent any type of fuel cell. A solid oxide fuel cell (SOFC) has been modeled in this chapter. ${ }^{1}$

\section{A. The Fuel Cell Blackbox}

The fuel cell is treated simply as a two terminal voltage source with an internal resistance. With increase in current, the fuel cell terminal voltage drops due to polarization losses as described in Chapter II, resulting in a non-linear voltage-current characteristic. Consequently, the internal resistance is also non-linear. This non-linearity can be modeled using curve-fitting techniques. Thus, complicated thermodynamic and electrochemical equations that are commonly used to model the fuel cell are avoided. Instead, the experimental data from an actual fuel cell are used to replicate the fuel cell electrical behavior under various conditions.

B. Modeling the Fuel Cell Steady State Behavior

The experimental voltage-current data of the $5 \mathrm{~kW}$ solid oxide fuel cell (SOFC) built by Fuel Cell Technologies, Ltd are given in Table III. Fig. 14 shows the data points that are curve-fitted using quadratic, cubic, and fourth order polynomials. The cubic polynomial provides the best curve fit for this data set as compared to the quadratic

1* (C) 2004 IEEE. Reprinted, with permission, from "An advanced fuel cell simulator" by P. Acharya, P. Enjeti and I. J. Pitel, $19^{\text {th }}$ Annual IEEE Applied Power Electronics Conference and Exposition, 2004, Volume 3, pp 1554-1558. 
Table III. Experimental V-I Data for a 5kW SOFC

\begin{tabular}{|r|r|}
\hline Voltage (V) & Current (A) \\
\hline 41.0 & 0 \\
38.0 & 0.01 \\
34.0 & 27 \\
32.0 & 44 \\
31.0 & 64 \\
29.5 & 100 \\
29.0 & 115 \\
28.5 & 132 \\
28.0 & 142 \\
27.5 & 146 \\
27.0 & 150 \\
22.0 & 275 \\
\hline
\end{tabular}

fit that gives a rough approximation, and as compared to the fourth order polynomial that shows oscillations at higher currents. The fourth and higher order polynomials show oscillations because the data set is not evenly spaced and is ill-conditioned.

A cubic polynomial fit is used on the experimental data to obtain a smooth voltage-current (V-I) curve. Since polynomial curve fitting is an approximation method, the best result is obtained if there are several points in the data set and the points are evenly spaced. Fig. 15 shows the experimental data points and the V-I curve for the steady state electrical characteristics of an actual 5kW SOFC provided by Fuel Cell Technologies, Ltd. In addition, the relation between output power and current (P-I curve) is also shown.

The equation for the cubic polynomial is given as

$$
V=-2.547 \times 10^{-6} I^{3}+1.187 \times 10^{-3} I^{2}-0.1967 I+39.2082
$$

where $\mathrm{V}$ is the fuel cell terminal voltage and $\mathrm{I}$ is the current. The minimum least- 


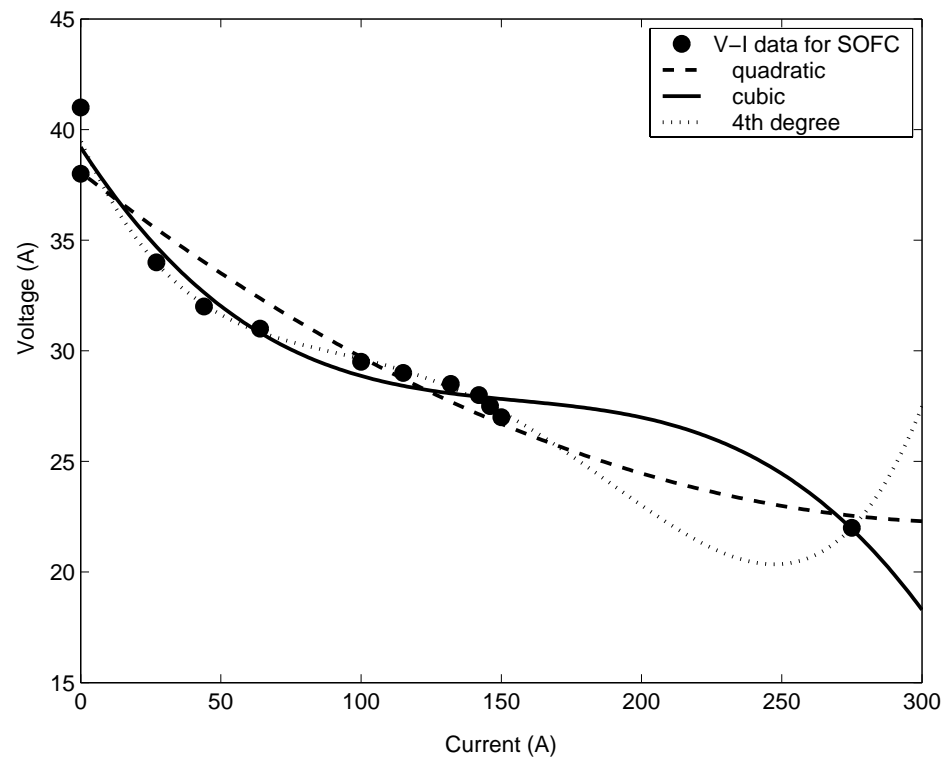

Fig. 14. V-I Curve-fitting with Quadratic, Cubic and Fourth Order Polynomials

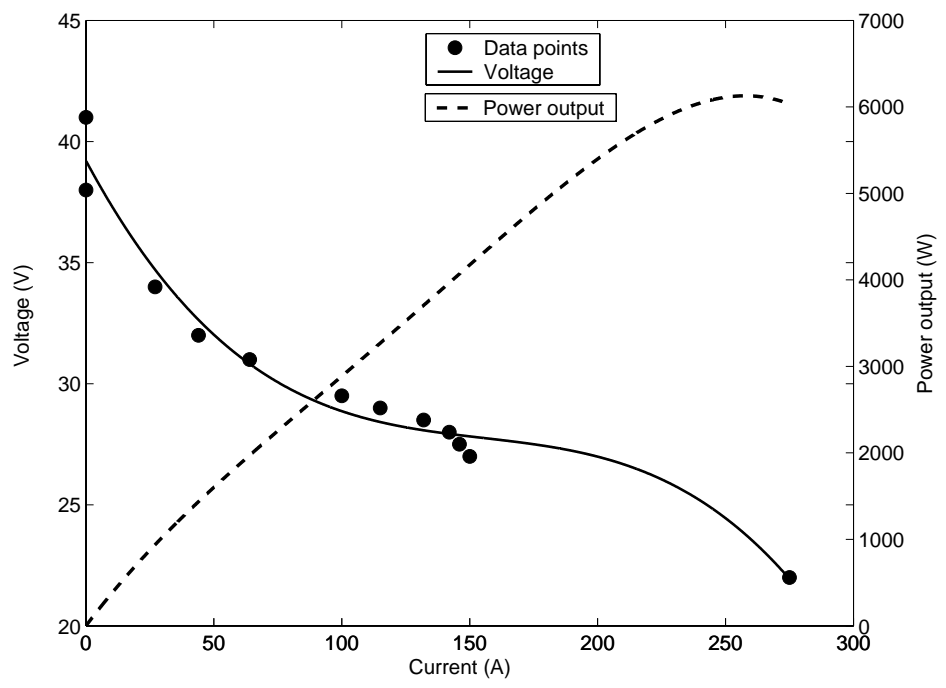

Fig. 15. Electrical Characteristics for a 5kW SOFC Built by Fuel Cell Technologies, Ltd. 
squares error method is used to obtain the closest approximation.

An increase in the load results in an increase in fuel cell power output and consequently an increase in the current and a drop in the terminal voltage. The fuel cell P-I curve is a steadily increasing curve and thus for a given value of power output the operating point on the V-I curve is unique and can be expressed as follows

$$
\begin{aligned}
\text { Power output } & =\text { Power demanded by load } \\
V \times I & =I^{2} \times Z \\
V & =I \times Z
\end{aligned}
$$

where $\mathrm{Z}$ is the load impedance. Equations (3.1) and (3.2) are solved simultaneously to obtain an equation in terms of the current and the load impedance as follows

$$
f(I)=-2.547 \times 10^{-6} I^{3}+1.187 \times 10^{-3} I^{2}-(0.1967+Z) I+39.2082=0
$$

The Newton-Raphson iterative method is employed to solve the non-linear equation (3.3) and determine the fuel cell current. The method for solving an equation $f(x)=0$ is outlined as follows [16]

$$
x_{n+1}=x_{n}-\frac{f\left(x_{n}\right)}{f^{\prime}\left(x_{n}\right)}
$$

where $x_{n}$ is the estimate at the $\mathrm{n}^{\text {th }}$ iteration and $x_{n+1}$ is the updated estimate.

The iteration process is terminated when $f\left(x_{n+1}\right)<=\epsilon \approx 0$, where $\epsilon$ is the tolerance limit and $x_{n+1}$ is the required solution. The method is terminated if $f^{\prime}\left(x_{n}\right)=$ 0 , since it diverges away from the solution and a new initial guess is used and the process repeated.

Being a numerical method the condition for convergence has to be satisfied. For the Newton-Raphson method the first order derivative of the function should not be 
zero.

The first order derivative for (3.3) is calculated as follows.

$$
f^{\prime}(I)=-7.642 \times 10^{-6} I^{2}+2.375 \times 10^{-3} I-(0.1967+Z)
$$

Since (3.5) is a quadratic equation, in order for the roots to be real the discriminant has to be greater than or equal to zero. From (3.5), this implies, $Z \leq-0.0122$. This value is not practically possible since the load impedance is not negative for a fuel cell power system being simulated. Thus, the condition for convergence is fulfilled. The Newton-Raphson method is chosen to solve the non-linear equation because of two reasons: it is of the second order and the condition for convergence is satisfied.

A reasonable starting guess is assumed such that it lies within the bounds defined by the V-I curve. For the given fuel cell data, the current varies from $\sim 0 A$ to $275 A$. The load impedance varies from $360 \Omega$ for a current of $0.1 A$ to $0.08 \Omega$ at a full load current of $275 A$. Fig. 16 shows the number of iterations required to converge to a solution using the Newton-Raphson for a range of initial guesses when load impedance is $0.17 \Omega$. The error tolerance is set at $10 \mu \mathrm{A}$.

C. Modeling the Fuel Cell Transient Behavior

Changes in parameters like temperature, pressure, hydrogen flow rate and variation in the load can cause the fuel cell to display transient behavior.

\section{Sudden Increase in Load}

High temperature fuel cells with reformers have a low slew rate, because of the time required to reform the extra fuel and increase the fuel cell temperature to supply more power. A sudden increase in power demand causes the fuel cell voltage to drop 


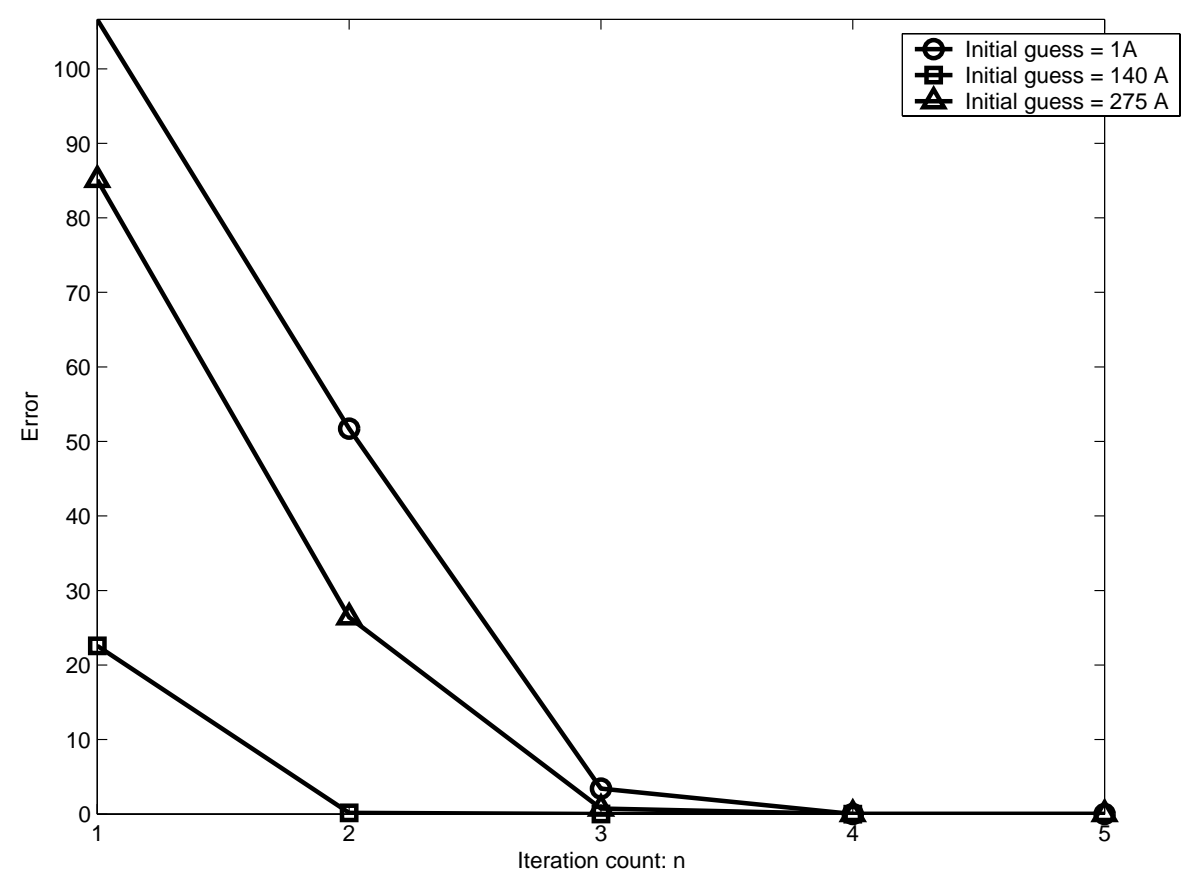

Fig. 16. Convergence for Different Initial Guesses

sharply. The SOFC takes some time to supply the additional power and eventually the terminal voltage climbs back to the steady state value.

This transient behavior is modeled in the simulator by two configuration parameters viz. the slew rate and the current limit. Their values can be adjusted depending on the fuel cell. The current limit sets the amount of current that can be drawn when there is a increase in power demand. In case the demand is excessive then the current is limited and the terminal voltage drops emulating the fuel cell transient. The fuel cell output power is increased by a rate equal to the slew rate till the power demand is met. 


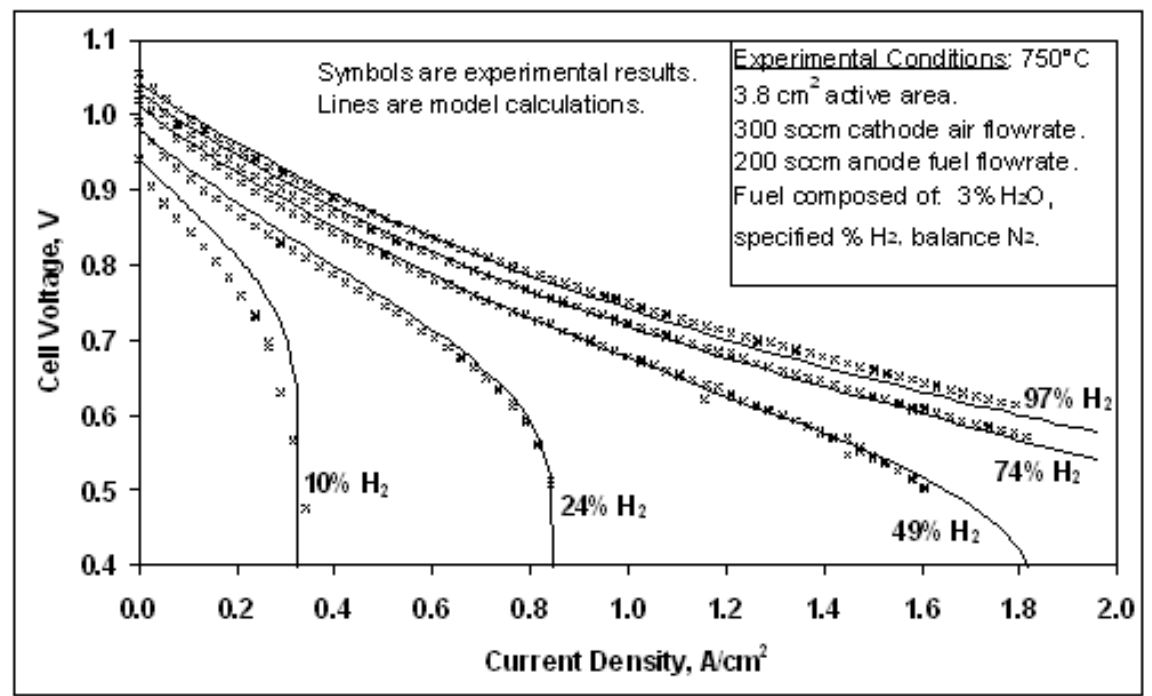

Fig. 17. Effect of Hydrogen Fuel Concentration on SOFC Voltage and Current Density

\section{Decrease in Hydrogen Flow Rate}

The amount of fuel (hydrogen) supplied to a fuel cell determines the power generation capacity of the fuel cell. If the hydrogen supplied to the fuel cell is reduced then the fuel cell power output decreases, the polarization losses increase and the terminal voltage of the fuel cell decreases as shown in Fig. 17 [6].

The voltage and current for various hydrogen flow rates are obtained experimentally and curve fitting is done, similar to the steady state modeling. Once the simulator is configured, the hydrogen flow rate is accepted dynamically and the simulator replicates the fuel cell transient behavior for varying hydrogen flow rate. 


\section{Fuel Cell Simulator Algorithm}

The mathematical modeling for the steady state and transient behavior described in the previous section is simulated and tested using MATLAB. A high level flowchart of the simulator program is shown in Fig. 18. The first step is to configure the simulator using the experimental V-I data of a particular fuel cell. The cubic polynomial equations fitting the steady and transient behavior are determined.

The simulator starts off at the open circuit voltage of the fuel cell and measures the voltage and the current at the output terminal. This feedback data is used to calculate the load impedance. Utilizing the value for load impedance, the cubic polynomial is solved iteratively using the Newton - Raphson method to calculate the fuel cell operating current and voltage. Based on the fuel cell slew rate the output current limit is calculated. The simulator output voltage and current limit is updated. Again the fuel cell output voltage and current is read and whole process is repeated to calculate a latest operating point. In case the hydrogen flow rate changes, the transient is simulated by using the cubic polynomial corresponding to the lower hydrogen flow to find the operating point. In case there is a sudden increase in load demand, the current limit restricts the current drawn. The system goes in transient mode and based on the slew rate the current limit is increased till the power output meets the power demand. A stop signal causes the simulator to terminate and exit. 


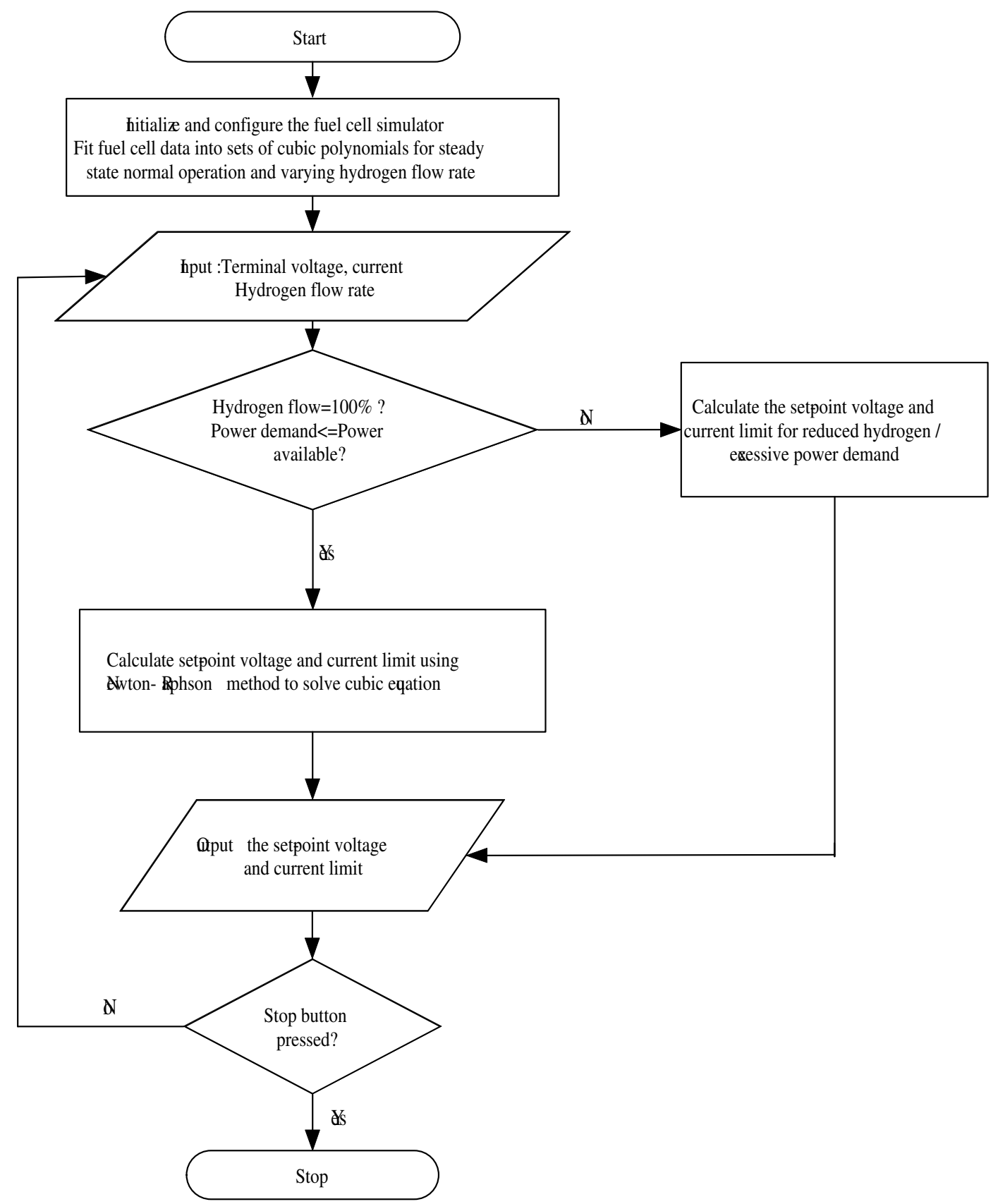

Fig. 18. Flowchart for the Fuel Cell Simulator 


\section{CHAPTER IV}

\section{IMPLEMENTATION OF THE SIMULATOR AND RESULTS}

The components of the fuel cell simulator and the experimental setup are described in this chapter. The design specifications laid down by the US Department of Energy, National Energy Technology Laboratory (US DOE-NETL) are stated.

\section{A. Design Example}

The requirements provided by the US DOE-NETL for the Future Energy Challenge 2003 were used as a reference for designing the fuel cell simulator. The specifications are given as follows [17].

The fuel cell simulator should provide a voltage and current representative of a real fuel cell, both in steady state behavior as well as in its transient behavior. It should simulate transients due to changes in volume of anode gas, or changes in reformate gas transport time from the reformer to the anode, or changes in cathode electrochemical reactivity. A computer interface should be provided allowing the user to modify some parameter values. The capability of modifying the fuel cell model itself would be desired, however the system must come preprogrammed with at least one SOFC-based model. The system should be built according to any applicable National Electric Code (NEC) standards for safety. At a minimum, the system should be self-protected against any internal failures as well as any inverter failures during operations such as shorts, power feedback into the simulator. Desired capability is listed as follows.

1. FCS input requirements: Input power $120 \mathrm{~V} \mathrm{AC,} 240 \mathrm{~V}$ AC or $480 \mathrm{~V}$ AC. Cooling water at less than $3 \mathrm{gpm}$. 
2. Simulated fuel cell auxiliary loads: $120 \mathrm{~V} \mathrm{AC}, 60 \mathrm{~Hz}, 1 \mathrm{~kW}$. Programmable for 0-48 V DC, 0-300 W. (Not implemented)

3. FCS simulated stack output: Output is defined for two voltage ranges and should transition seamlessly between the two. Ranges are 15-22 V DC with current in $0-275 \mathrm{~A}$ and $22-60 \mathrm{~V}$ DC with current limited by maximum power of $6 \mathrm{~kW}$.

4. Physical parameters: The simulator can be provided by multiple components, but each component should fit through standard doorways: less than 70 inches high, less than 25 inches wide and less than 30 inches deep. Weight should be less than $150 \mathrm{lb}$ for any component. Unit shall be self-contained and be mounted on casters or other means for portability. Forced cooling vented by air flow over fins for electronics, water-cooled for DC load. Noise level should be less than $65 \mathrm{~dB}$ at $10 \mathrm{ft}$.

5. Interface for control:

(a) Inverter RS-485 communications: Control signals from the simulator to inverter are listed as follows. (Implemented with changes)

- Stand alone voltage command (Vac range dependent on application)

- Fuel cell current command (0-275A)

- Output frequency $(50-60 \mathrm{~Hz})$

- Battery float voltage (52.8-55.9V DC)

- Minimum battery voltage (43-57V DC)

- Minimum fuel cell voltage (21-41V DC)

- Output power enable (on/off) 
- Fault reset

- Slew rate

Feedback from inverter to simulator are as follows.

- Stand alone voltage command readback

- Fuel cell current command readback

- Output frequency readback

- Battery float voltage readback

- Minimum battery voltage readback

- Minimum fuel cell voltage readback

- Output power enable readback

- Stand alone voltage readback

- Stand alone current readback

- Inverter status to include $\mathrm{AC}$ line $\mathrm{OK}$ and phase locked to $\mathrm{AC}$ line indicators as well as fault indicators as required such as battery or fuel cell undervoltage

- Battery voltage readback

- High voltage bus readback

- Fuel cell input voltage readback

(b) Inverter digital control: The following is a list of TTL signals that the simulator must make available to the inverter.

- Power supply enable

- High voltage bus enable

(c) Inverter analog control: The control signals from the simulator to the inverter are as follows. 
- Stand alone voltage command (0-10V DC)

- Fuel cell current command (0-10V DC)

\section{B. Components}

The fuel cell simulator (FCS) comprises of the power, the measurement, the communication and the control elements. The power block is made up of a DC programmable power supply. The SBC488A interface forms the communication channel between the computer and the power supply. The measurement system is made of a signal conditioning module with analog and digital voltage input/output devices, which measure feedback signals from the device under test (DUT) into the computer. A data acquisition (DAQ) card interfaces between the computer and the measurement system. The fuel cell simulator program executed on the computer is the controller for the system. Fig. 19 shows the interaction between the various components whose details are given as follows.

1. Power supply: Two programmable DC power supplies manufactured by MagnaPower Electronics are connected together in a master-slave mode. Each of them requires three phase $208 \mathrm{~V}$ AC power supply and has a rated output of $10 \mathrm{~kW}, 0$ $55 \mathrm{~V} \mathrm{DC}, 180 \mathrm{~A}$. The outputs of the two power supplies are connected in parallel so as to obtain a current capacity of $360 \mathrm{~A}$.

2. SBC488A control interface: This is provided by Magna-Power Electronics and forms the interface between the computer and the DC power supply. It has a IEEE-488 (GPIB - General Purpose Interface Board) interface bus and a RS232 serial port, and either of these two can be used to connect the computer to the power supply. The computer can command the power supply using Standard Commands for Programmable Instruments (SCPI). The SBC488A 


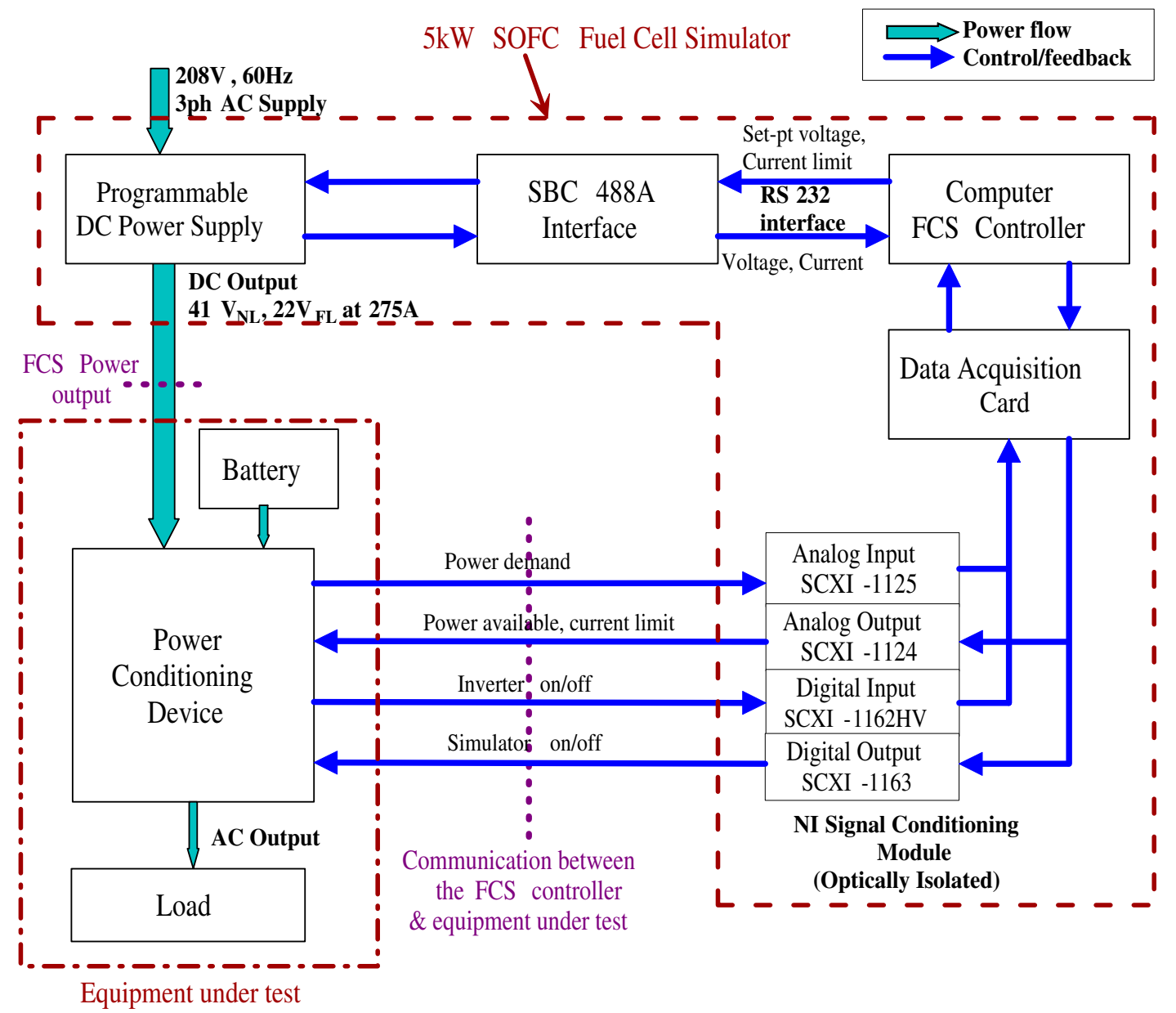

Fig. 19. Schematic of the Fuel Cell Simulator 
provides optical isolation between the communication bus and the power supply.

3. Signal conditioning and analog and digital input/output modules: The NI-SCXI signal conditioning platform is used. It comprises of analog and digital input output modules installed in a rugged SCXI-1000 chassis. The chassis provides a housing for the modules and is cabled to the DAQ card. The SCXI-1125 analog input module provides 8 channels with $300 \mathrm{~V}_{r m s}$ working isolation per channel and a low pass filter. The SCXI-1124 is an optically isolated 6 channel analog output module with $250 \mathrm{~V}_{\text {rms }}$ working isolation per channel and a 12bit resolution. The SCXI-1162HV digital input module has 32 digital inputs with optical isolation of $300 \mathrm{~V}_{r m s}$ per bank of 4 lines. The SCXI-1163 optically isolated module has 32 digital outputs with $300 \mathrm{~V}_{r m s}$ isolation per bank of 4 lines $[18]$.

4. Data acquisition card: A National Instruments (NI) E-series PCI-6070E card is used as an interface between the signal conditioning module and the computer. This DAQ card has a maximum sampling rate of $1.25 \mathrm{MS} / \mathrm{s}$ with 12-bit resolution. It has 16 analog inputs, two 12-bit analog outputs, 8 digital input/output lines and two 24-bit counters [19].

5. Simulator software: The simulator controller implements the algorithm described in Chapter III along with a graphical user interface (GUI). The controller is written in LabVIEW and executed on a personal computer running Windows $\mathrm{XP}$ operating system. The software is platform independent and can be ported onto computers running other operating systems.

Fig. 20 shows photographs of the actual components. 


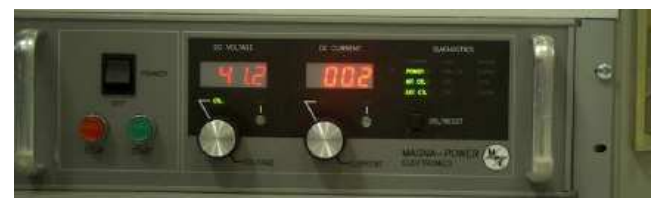

Programmable D Power Supply

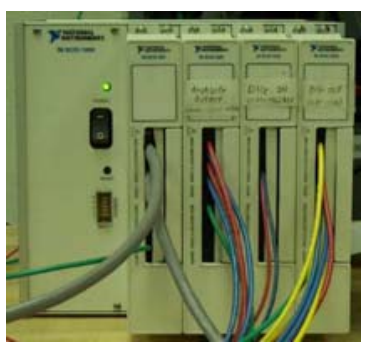

Đa eqistion \&

Signal Conditioning Mlule

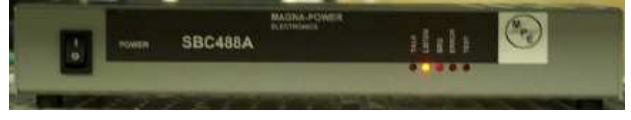

SB $\$$ hterface

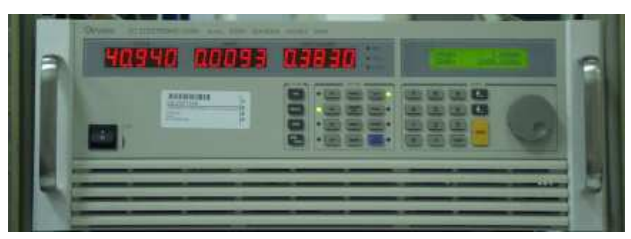

D Electronic bad

Fig. 20. Components of the Fuel Cell Simulator 


\section{Working of the Fuel Cell Simulator}

The DC programmable power supply receives an input of $208 \mathrm{~V}, 60 \mathrm{~Hz}$ three phase AC supply and provides an output emulating the fuel cell. It is operated in a voltage controlled mode and is controlled externally from a computer program. The output of the power supply is connected to the device under test (DUT). Two 25 pin connectors cable the power supply to the SBC488A box, which is connected to the computer at the RS232 serial port, also known as the COM port. This forms a two-way communication channel between the computer and the power supply and the computer program uses SCPI commands to send or receive information. The signal conditioning module communicates with the DUT using analog and digital input/output. The analog input channel reads the value of the power required which is provided as a voltage scaled to a range of $0-5 \mathrm{~V}$. The power available at the FCS terminal is scaled to a $0-5 \mathrm{~V}$ voltage and provided at the analog output channel. The digital lines with 0 or $5 \mathrm{~V}$ values are used to indicate the status of the simulator and the DUT. The signal conditioning modules are connected to the DAQ card which is installed on the PCI bus of the computer.

The fuel cell simulator controller software implements the algorithm described in Chapter III, Fig. 18 and is executed on the computer. The FCS controller program provides a graphical user interface (GUI) as well as the back-end processing software for the fuel cell simulator. Fig. 21 shows the main screen of the fuel cell simulator. The controller main GUI displays the FCS output voltage, output current, the power available, the power output, the set-point voltage, the current limit and accepts the hydrogen flow rate. The steady state V-I characteristic of the fuel cell is plotted on a graph as a reference and the present operating point of the simulator is displayed. The Start and Stop buttons allow the user to control the simulator. The Reset 


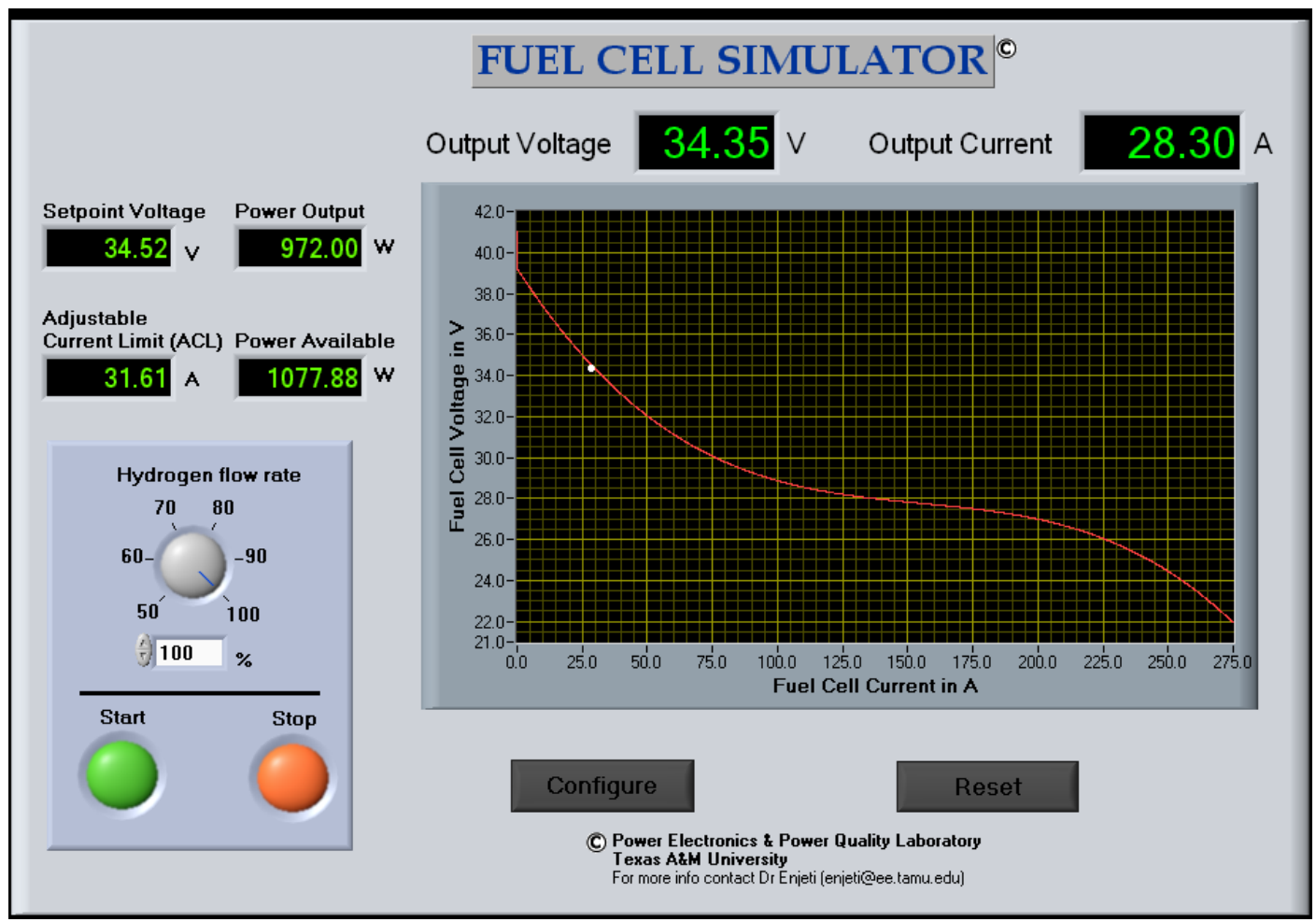

Fig. 21. Fuel Cell Simulator - Graphical User Interface

button clears fault states and resets the power supply. The Configure button allows the user to input the V-I data of the fuel cell being simulated, the slew rate and the reserve current limit as shown in Fig. 22. Also the over-voltage, under-voltage and over-current protection for the power supply can be set. Fig. 23 shows the transitions between the various states of the simulator. After the configuration data are entered, the cubic polynomial equations are generated. Additionally, the information is saved to a file on the computer for later use. The simulator is started when the Start button is pressed. The FCS controller uses SCPI instructions to set the terminal voltage and current limit of the power supply and also to receive information about the output 


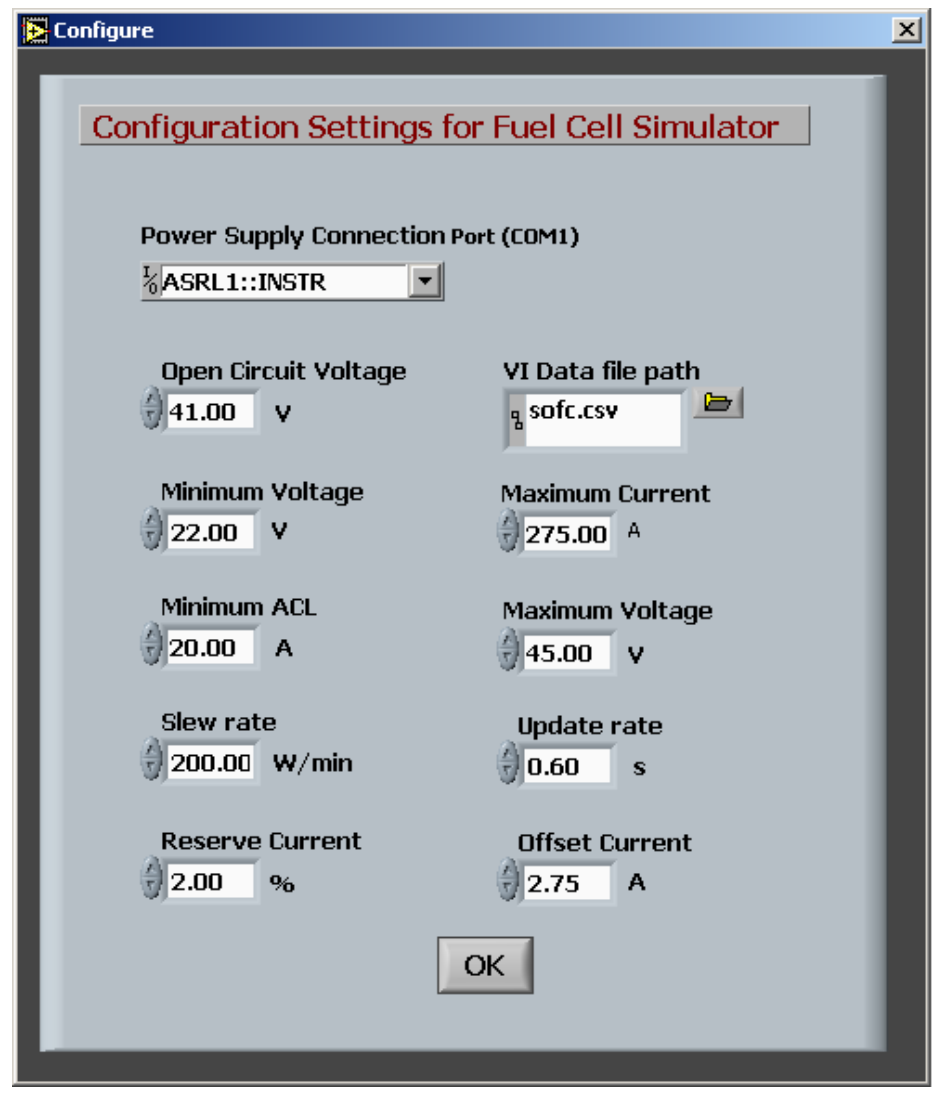

Fig. 22. Fuel Cell Simulator - Configuration Screen 


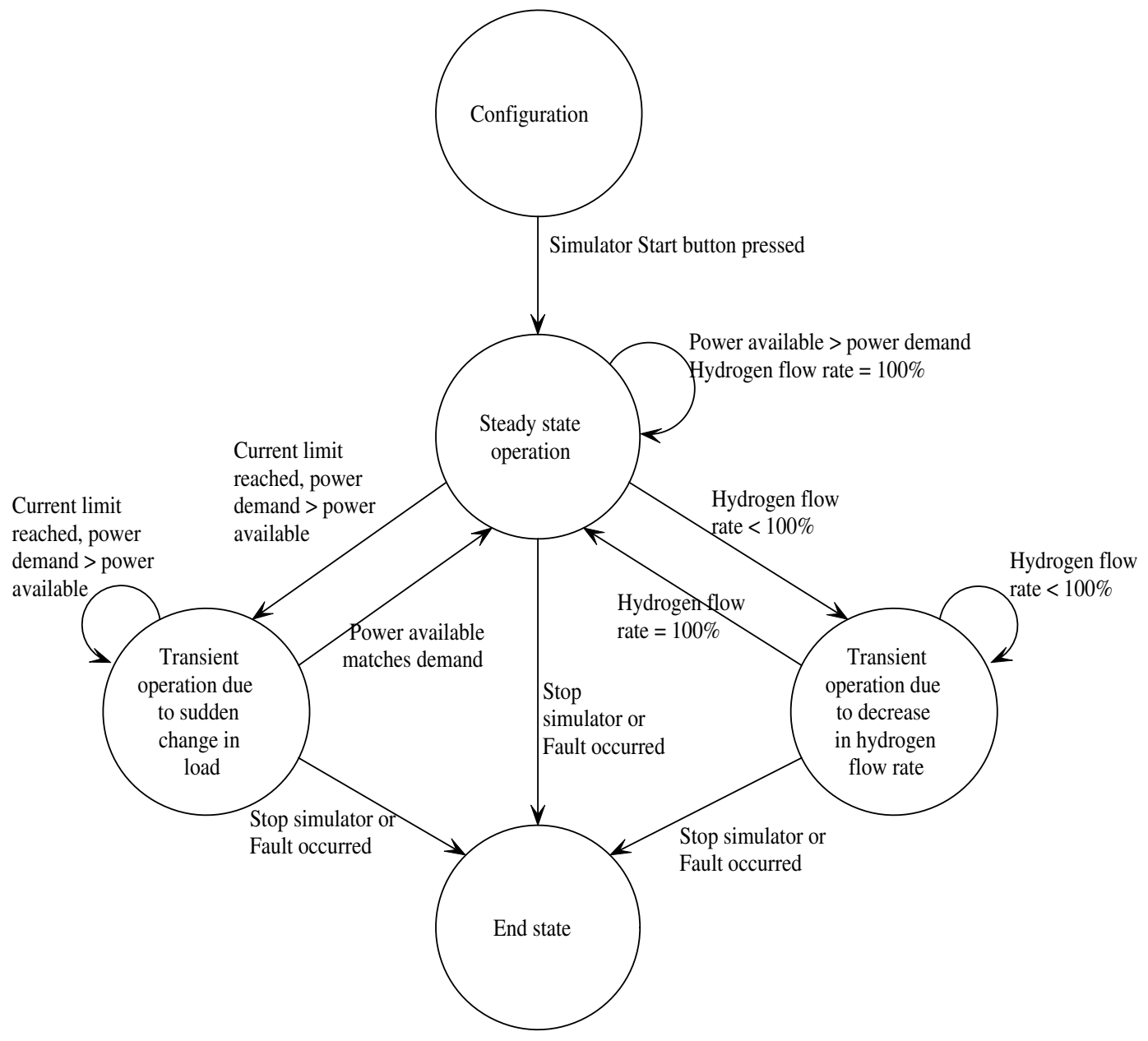

Fig. 23. Fuel Cell Simulator - State Diagram 
voltage and current. The instructions are sent over the RS232 serial interface to the SBC488A which controls the power supply. In the steady state, the load at the terminal is measured, and the FCS controller solves the non-linear cubic equation using the Newton-Raphson technique to determine the output voltage, which is also known as the set-point voltage. This value is communicated to the power supply in real-time and its output changes to match an actual fuel cell output under similar conditions.

For simulating effect of a sudden increase in load, the controller sets another parameter called the current limit of the power supply. Reserve current limit, a userconfigurable parameter, determines how much extra current can be drawn at any instant without causing transients. If the load tries to draw more current than the allowed limit, then simulator shifts to the transient state. The power supply operates in a current controlled mode and consequently the voltage drops, replicating the fuel cell behavior. The controller senses the increased load demand and the fuel cell output power is increased based on the fuel cell slew rate as configured by the user. When the power available at the FCS matches the load demands, the transient operation ends and the steady state is resumed. If the hydrogen flow rate decreases, the program chooses the appropriate cubic polynomial and the FCS output voltage drops. When the hydrogen flow rate resumes normal values, the program switches to the steady state V-I curve and output voltage increases. The Stop button terminates the fuel cell simulator. The controller also detects the following fault states and terminates the simulator.

- Terminal voltage exceeds the maximum voltage

- Terminal current exceeds the maximum current

- Terminal voltage drops below the minimum voltage 
- Communication with the power supply over the serial port fails

- Communication with the DAQ card and signal conditioning modules fails

The fuel cell simulator implements most of the specifications given by the US DOE-NETL. However, the control and communication interface have been changed to suit more generalized requirements.

The input requirements are fulfilled since the DC power supply uses $208 / 240 \mathrm{~V}$ $\mathrm{AC}$ input and no cooling water is required. Fuel cell auxiliary loads have not be simulated. The power supply can provide a maximum voltage of $55 \mathrm{~V}$ DC and current upto $360 \mathrm{~A}$. The simulator consists of separate components and each are within the specified limits for size and weight. Implementing the above mentioned control interface would make the simulator very specific to inverters that can respond to the commands. The inverters would have to be designed with this control interface as well. To increase the usability of the simulator, the communication between the simulator and the device under test (DUT) is minimized and simplified by using analog voltage input/output. The simulator provides the value of the power available in the form of an analog voltage scaled down to 0-5 V DC. The inverter communicates with the simulator about the power required by setting the analog input (into the FCS controller) scaled identically as the simulator output value. The simulator ON/OFF status is sent out as a TTL signal on the digital output line. Similarly the inverter $\mathrm{ON} / \mathrm{OFF}$ status is present on the digital input line.

\section{Testing and Results}

The simulator has been tested for steady state and transient modes of operation using an electronic resistive load. Values set during the configuration mode of the fuel cell simulator are given in Table IV. 
Table IV. Configuration Settings for the Fuel Cell Simulator

\begin{tabular}{|l|r|}
\hline Parameter & Value \\
\hline Open circuit voltage & $41 \mathrm{~V}$ \\
Minimum voltage & $22 \mathrm{~V}$ \\
Slew rate & $200 \mathrm{~W} / \mathrm{min}$ \\
Update rate & $0.60 \mathrm{~s}$ \\
Minimum current limit & $20 \mathrm{~A}$ \\
Reserve current & $2 \%$ \\
Offset current & $2.75 \mathrm{~A}$ \\
\hline
\end{tabular}

\section{Steady State Mode}

The power demand is varied in small steps to check whether the fuel cell simulator follows the slow changes in the load. The expected values of the output voltage $\left(\mathrm{V}_{\text {cal }}\right)$ and current $\left(\mathrm{I}_{\text {cal }}\right)$ are calculated by solving (3.3) and (3.1). The actual values of the output voltage $\left(\mathrm{V}_{\text {expt }}\right)$ and current $\left(\mathrm{I}_{\text {expt }}\right)$ are read using an oscilloscope connected at the load terminals. The testing results are summed up in Table V. The variation of voltage and current with time measured by the oscilloscope is shown in Fig. 24. The current and the voltage increase steadily and takes $500 \mathrm{~ms}$ to settle to the final value. This is the due to the delay caused during measuring changes, communicating the new set-point voltage value and the response time of the power supply.

Table V. Test Results for Steady State Operation

\begin{tabular}{|r|r|r|r|r|r|}
\hline $\mathbf{V}_{\text {cal }}(\mathbf{V})$ & $\mathbf{V}_{\text {expt }}(\mathbf{V})$ & $\mathbf{I}_{\text {cal }}(\mathbf{A})$ & $\mathbf{I}_{\text {expt }}(\mathbf{A})$ & $\mathbf{P}_{\text {output }}(\mathbf{W})$ & $\mathbf{P}_{\text {avail }}(\mathbf{W})$ \\
\hline 35.95 & 35.6 & 0.89 & 0.81 & 28.86 & 714.58 \\
34.95 & 34.1 & 11.65 & 11.40 & 388.74 & 714.58 \\
\hline
\end{tabular}




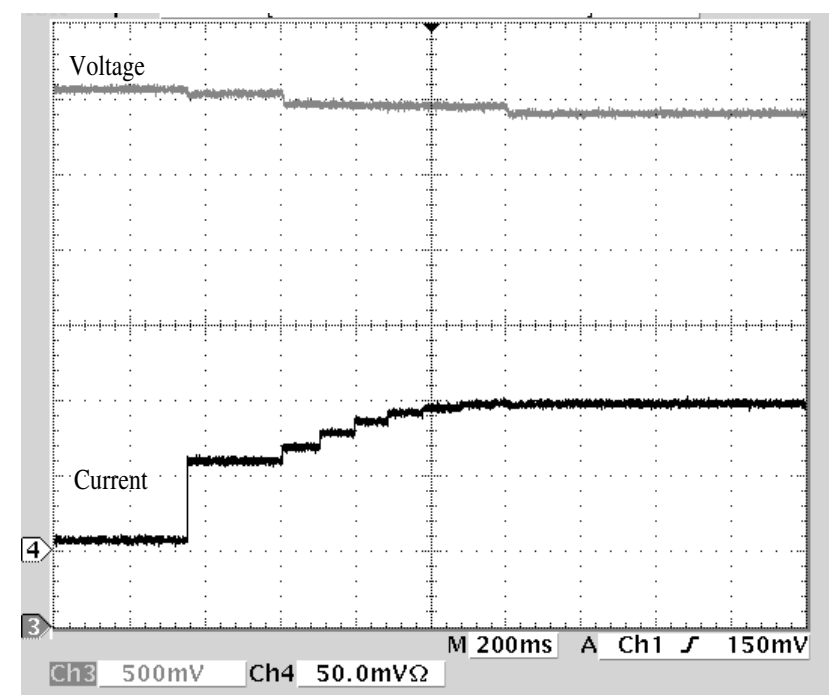

Fig. 24. FCS Voltage and Current vs Time for Steady State Operation

\section{Transient Mode}

1. Sudden increase in load

The load is increased suddenly, such that power demand is much more than the power available at the simulator. The expected response is a steep drop in the output voltage and the current limited by the reserve capacity of the simulator. This marks the start of the transient mode of operation. The current limit is increased depending on the fuel cell slew rate $(200 \mathrm{~W} / \mathrm{min})$ till the output power matches the demand and the transient mode ends and steady state operation is resumed. The steady state values of the output voltage $\left(\mathrm{V}_{\text {cal }}\right)$ and the current $\left(\mathrm{I}_{\text {cal }}\right)$ are calculated by solving (3.3) and (3.1) for the given load impedance. The actual values of the output voltage $\left(\mathrm{V}_{\text {expt }}\right)$ and current $\left(\mathrm{I}_{\text {expt }}\right)$ are read using an oscilloscope connected at the load terminals. The results are summed 


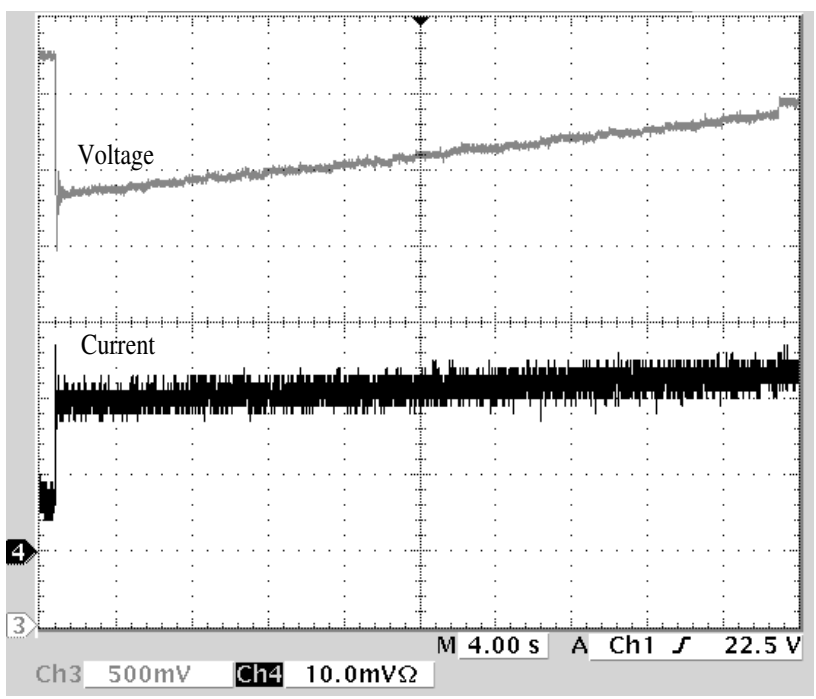

Fig. 25. FCS Voltage and Current vs Time for Sudden Increase in Load

up in Table VI. The variation of voltage and current with time measured by the oscilloscope is shown in Fig. 25. A sharp drop in the output voltage can be observed in the initial part of the test. For this test case, the expected time for transient operation is calculated to be around 42 seconds. The measured value was around 39 seconds. The difference in the expected and measured value is because of the reserve current capacity.

Table VI. Test Results for Sudden Increase in Load

\begin{tabular}{|r|r|r|r|r|r|}
\hline $\mathbf{V}_{\text {cal }} \mathbf{( V )}$ & $\mathbf{V}_{\text {expt }}(\mathbf{V})$ & $\mathbf{I}_{\text {cal }}$ (A) & $\mathbf{I}_{\text {expt }}(\mathbf{A})$ & $\mathbf{P}_{\text {output }}(\mathbf{W})$ & $\mathbf{P}_{\text {avail }}(\mathbf{W})$ \\
\hline 36.6 & 37.4 & 7.32 & 7.05 & 265.9 & 714.58 \\
34.4 & 34.3 & 24.6 & 24.2 & 857.89 & 955.11 \\
\hline
\end{tabular}




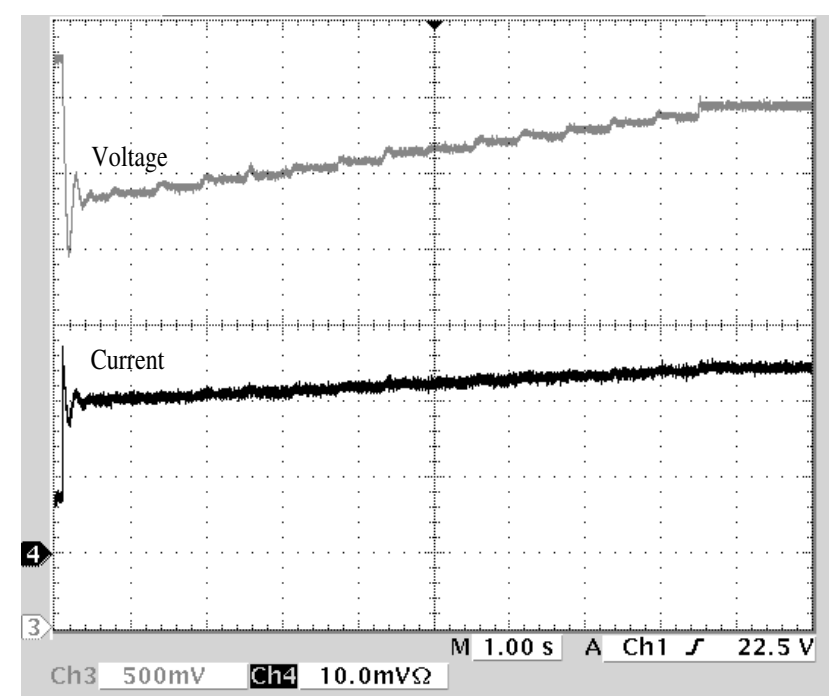

Fig. 26. Effect of Slew Rate on the Simulator Voltage and Current

\section{Effect of slew rate}

The previous test is repeated with a different value of slew rate $(1000 \mathrm{~W} / \mathrm{min})$. The expected time of transient operation is 8 seconds, and the measured value is 7 seconds. Fig. 26 shows the transient behavior with a higher slew rate.

\section{Change in hydrogen flow rate}

When the hydrogen flow rate is decreased, the expected output is a drop in the output voltage and power. The expected values of the output voltage $\left(\mathrm{V}_{\text {cal }}\right)$ and current $\left(\mathrm{I}_{\text {cal }}\right)$ are calculated by solving the equation corresponding to lower hydrogen flow rate. The actual values of the output voltage $\left(\mathrm{V}_{\text {expt }}\right)$ and current $\left(\mathrm{I}_{\text {expt }}\right)$ are read using an oscilloscope connected at the load terminals. The hydrogen flow rate is decreased from $100 \%$ to $50 \%$. The testing results are summed up in Table VII. The variation of voltage and current with time measured by 


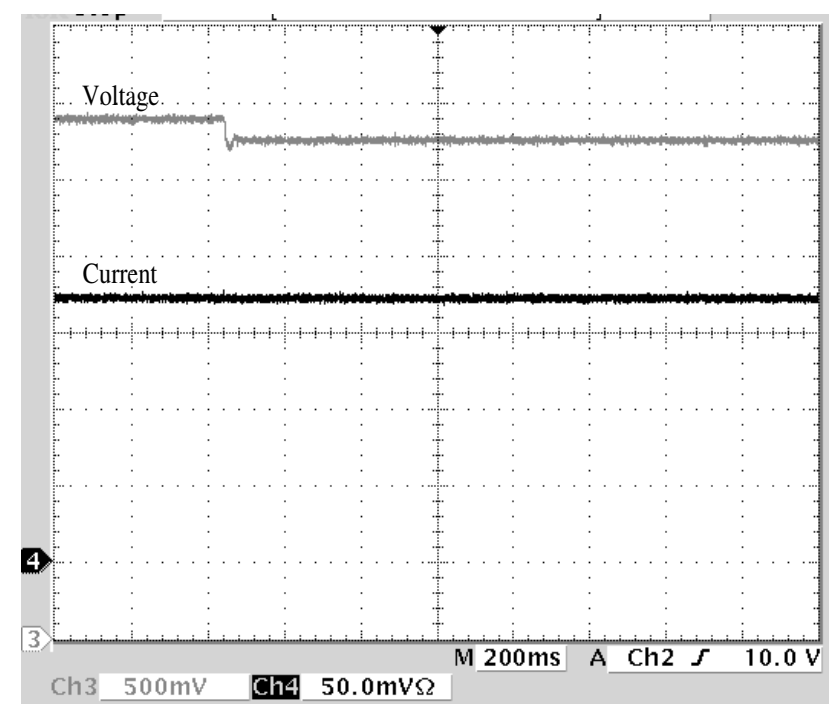

Fig. 27. Effect of Decrease in Hydrogen Flow Rate on the Simulator Voltage and Current

the oscilloscope is shown in Fig. 27.

Table VII. Test Results for Drop in Hydrogen Flow Rate

\begin{tabular}{|r|r|r|r|r|r|}
\hline $\mathbf{V}_{\text {cal }} \mathbf{( V )}$ & $\mathbf{V}_{\text {expt }}(\mathbf{V})$ & $\mathbf{I}_{\text {cal }}$ (A) & $\mathbf{I}_{\text {expt }}$ (A) & $\mathbf{P}_{\text {output }}(\mathbf{W})$ & $\mathbf{P}_{\text {avail }}(\mathbf{W})$ \\
\hline 34.28 & 34.0 & 26.36 & 26.3 & 910 & 1022.6 \\
32.77 & 32.6 & 25.21 & 25.2 & 825 & 921 \\
\hline
\end{tabular}

4. Under-voltage fault

If the increase in load is excessive, the current gets clamped at the value set by the adjustable current limit and consequently the terminal voltage can drop drastically. If the voltage drops below $22 \mathrm{~V}$, an under-voltage alarm is tripped and the simulator is switched off. The test results are summed up in Table VIII 


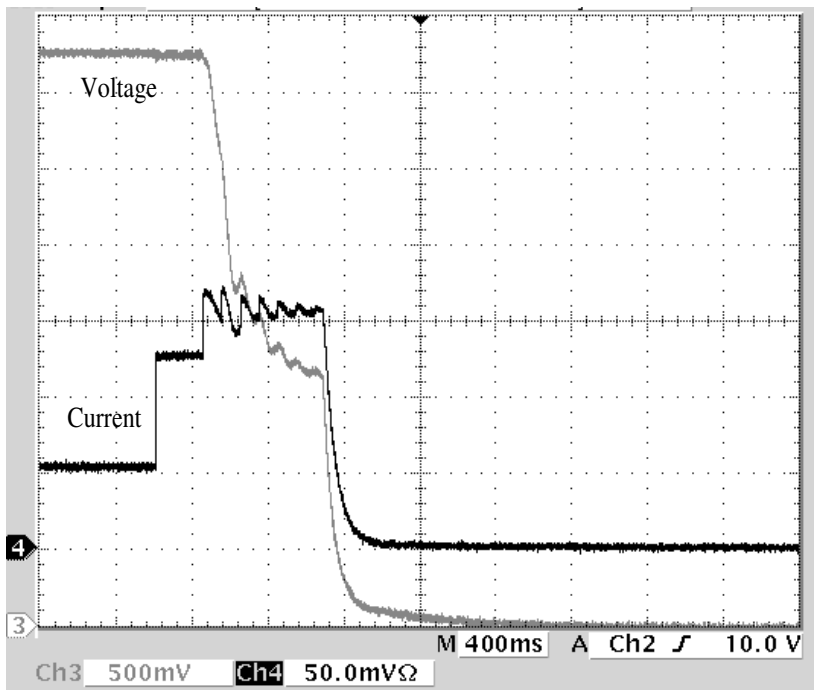

Fig. 28. Under-voltage Fault

and shown in Fig. 28.

Table VIII. Test Results for Under-voltage Fault

\begin{tabular}{|r|r|r|r|r|r|}
\hline $\mathbf{V}_{\text {cal }}(\mathbf{V})$ & $\mathbf{V}_{\text {expt }}(\mathbf{V})$ & $\mathbf{I}_{\text {cal }}(\mathbf{A})$ & $\mathbf{I}_{\text {expt }}(\mathbf{A})$ & $\mathbf{P}_{\text {output }}(\mathbf{W})$ & $\mathbf{P}_{\text {avail }}(\mathbf{W})$ \\
\hline 36.8 & 37.6 & 6.13 & 6.15 & 235 & 714.58 \\
31.17 & $20.67 \rightarrow 0$ & 38.97 & $19.5 \rightarrow 0$ & 0 & 0 \\
\hline
\end{tabular}




\section{CHAPTER V}

\section{CONCLUSIONS}

In this thesis, a fuel cell simulator was proposed based on the US Department of Energy-NETL specifications. The effect of various parameters such as load, hydrogen flow rate, temperature, and pressure on the fuel cell electrical output was studied. The fuel cell was modelled mathematically by cubic polynomials that approximate the non-linear voltage-current (V-I) characteristics. Steady state operation and transients due to sudden increase in power demand and hydrogen flow rate were successfully modeled and implemented in the simulator. A hardware-in-loop system was devised to replicate the fuel cell behavior.

A fuel cell simulator consisting of a programmable DC power supply, PC based controller, data acquisition card and signal conditioning modules was integrated. The feedback from the load was read into the controller and Newton-Raphson method was used to solve the cubic equations in real-time to determine the operating point of the simulator. A graphical user interface (GUI) was developed to allow the user to configure several parameters including fuel cell slew rate and reserve current capacity. The present operating status of the simulator was displayed on the GUI and a control was provided for the user to change the hydrogen flow rate.

Experimental results presented in Chapter IV show that the simulator mimics the electrical output of an actual fuel cell under steady state. The simulator also emulates the transients caused due to sudden load change and drop in hydrogen flow rate. The simulator comes preprogrammed with the (V-I) characteristic of a $5 \mathrm{~kW}$ solid oxide fuel cell but can be re-configured by the user to simulate other types of fuel cells.

The fuel cell simulator can act as a catalyst in speeding up the development and 
testing of converters, inverters and other power electronic devices. Since the simulator has the flexibility to emulate a wide range of fuel cells, it can provide a complete test platform representing many fuel cells, thereby decreasing the financial investment and space required for testing.

\section{A. Future Improvements}

The effect of parameters such as reactant pressure and stack temperature can be incorporated into the simulator. The minimum response time of the simulator is 0.5 s due to a bottleneck caused by the RS232 serial communication between the computer and the SBC488A module of the power supply. Using the GPIB interface provided by the SBC488A module instead of the RS232 interface can improve the response time of the system. The improved response will not have much impact on high-temperature fuel cell modeling because of the low slew rates of the fuel cells. However, the transients in a low-temperature fuel cells having a faster slew rate can be replicated more accurately. 


\section{REFERENCES}

[1] G. Hoogers, Fuel Cell Technology Handbook, Boca Raton, FL: CRC Press, 2003.

[2] A. J. Appleby and F. R. Foulkes, Fuel Cell Handbook, New York: Van Nostrand Reinhold, 1989.

[3] H. C. Maru, "Fuel cell systems and potential applications," Symposium Proceedings: Fuel Cells Technology Status and Applications, Institute of Gas Technology, Chicago, IL, pp. 33-44, November 1981.

[4] D. J. Hall and R. G. Colclaser, "Transient modeling and simulation of a tubular solid oxide fuel cell," IEEE Transactions on Energy Conversion, vol. 14, pp. 749-753, September 1999.

[5] D. J. Hall, "Transient modeling and simulation of a solid oxide fuel cell," Ph.D. dissertation, University of Pittsburgh, PA, 1997.

[6] L. A. Chick, R. E. Williford, J. W. Stevenson, C. F. Windisch Jr., and S. P. Simner, "Experimentally-calibrated, spreadsheet-based SOFC unit-cell performance model," Fuel Cell Seminar, Palm Springs, CA, 2002.

[7] S. Yerramala, A. Davari, and A. Feliachi, "Dynamic modeling and analysis of polymer electrolyte fuel cell," IEEE Power Engineering Society Summer Meeting, Edmonton, Alberta, Canada, vol. 1, pp. 82-86, July 2002.

[8] Q. Zeng, P. Song, and L. Chang, "A photovoltaic simulator based on DC chopper," IEEE Canadian Conference on Electrical and Computer Engineering, Winnipeg, Manitoba, Canada, vol. 1, pp. 257-261, May 2002. 
[9] H. Nagayoshi, S. Orio, Y. Kono, and H. Nakajima, "Novel PV array/module IV curve simulator circuit," $29^{\text {th }}$ IEEE Photovoltaic Specialists Conference, New Orleans, LA, pp. 1535-1538, May 2002.

[10] Elgar Electronics Corporation, "Solar array simulators," Available online at http://www.elgar.com/products/Elgar/sas.htm, accessed May 2004.

[11] Agilent Technologies, "Solar array simulators," Available online at http://we. home.agilent.com/upload/cmc_upload/All/SAS_datasheet_May04.pdf, accessed May 2004.

[12] Spectra-Nova Technologies Inc., "Solar array output simulators," Available online at http://www.spectra-nova.com/atesters.html, accessed May 2004.

[13] P. H. Chou, C. Park, J. Park, K. Pham, and J. Liu, "B\#: a battery emulator and power profiling instrument," Proc. International Symposium on Low Power Electronics and Design, Seoul, Korea, pp. 288-293, August 2003.

[14] J. Larminie and A. Dicks, Fuel Cell Systems Explained, Chichester, West Sussex: John Wiley \& Sons Inc., 2nd edition, 2003.

[15] EG\&G Technical Services Inc., "Fuel cell handbook (6th edition)," Tech. Rep., U.S. Department of Energy - N.E.T.L., 2002.

[16] E. Kreyszig, Advanced Engineering Mathematics, New York: John Wiley \& Sons, Inc., 7th edition, August 1992.

[17] U.S. Department of Energy N.E.T.L., "Fuel cell simulator," Solicitation number: DE-RQ26-03NT30094 (Request for proposal), January 2003. 
[18] National Instruments, "SCXI High-Performance Signal Conditioning," Available online at http://sine.ni.com/apps/we/nioc.vp?cid=1604\&lang=US, accessed May 2004.

[19] National Instruments, "E series Multifunction DAQ," Available online at http:// www.ni.com/pdf/products/us/4daqsc199-201_ETC_212-213.pdf, accessed May 2004. 
APPENDIX A

PROGRAMMABLE POWER SUPPLY BY MAGNA-POWER ELECTRONICS 


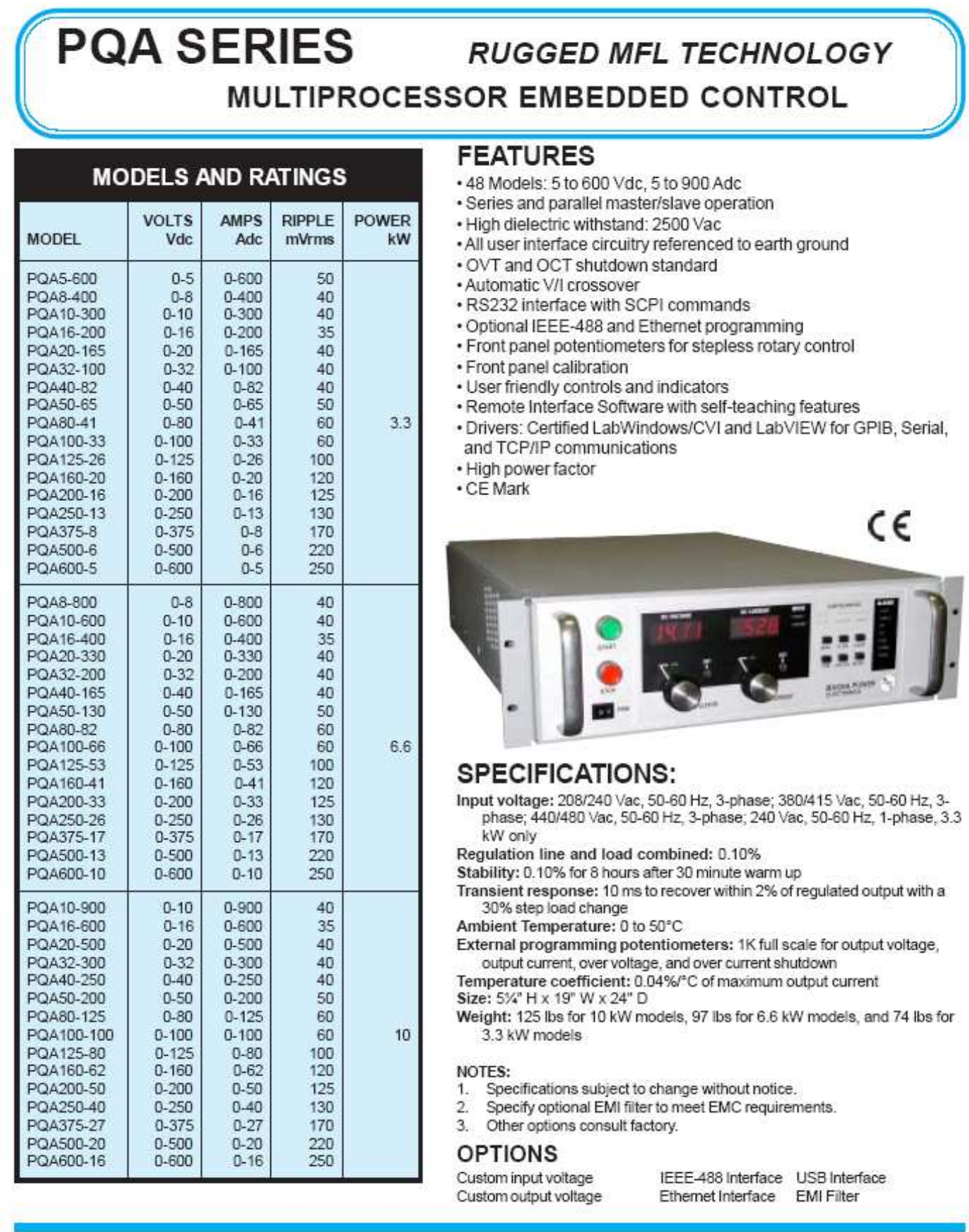

$\begin{array}{ll}\text { MaGNA-POWER } & \begin{array}{l}\text { 81 Fulton Street, Boonton, NJ 07005 } \\ \text { (973) 263-0017 FAX: (973) 263-1928 } \\ \text { E-mail: sales@magna-power.com } \\ \text { http://www.magna-power.com }\end{array} \\ \text { ELECTRONICS, INC. } & \end{array}$




\section{PQA SERIES COST AND PERFORMANCE ENHANCED CONTROLS AND DIAGNOSTICS}

Magna-Power Electronics' PQA SERIES combines the best of dc power processing with multiprocessor embedded control. A combination of high and medium frequency power processing technologies improves response, shrinks package size, and reduces cost. PQA SERIES power supplies are current fed and are more tolerant to abusive loads than conventional switching power supplies.

PQA SERIES power supplies offer an unusual blend of both analog and digital control. Two front panel potentiometers are available to set voltage and current for stepless analog control. Alternatively, voltage, current, over voltage trip, and over current trip may be programmed through a rear connector via resistance, voltage, or current. RS232 communications is embedded in the control circuitry allowing full computer control with SCPI commands. An optional IEEE-488 to RS232 converter, Ethernet to RS232 converter, and other communications converters are available to echo commands over the communications bus.

PQA SERIES power supplies can be configured through the front panel for different applications. The power supply can be programmed to have its control functions accessible from the front panel, rear connector, or through RS232 communications. Sensing can be established at the output terminal of the power supply or through a rear terminal block for sensing at the load. An external interlock can be set to enable operation only when an external connection is made. Even calibration has been simplified with front panel access to calibration digital potentiometers.

PQA SERIES power supplies incorporate an optically isolated feedback system. The result is that all user interface circuitry is reference to earth ground -- not the negative terminal of the power supply. This enables users to connect external circuitry without concern of ground loops or voltage breakdown.

PQA SERIES power supplies offer both master/slave parallel and series operation. This enables two or more power supplies to be placed in parallel for increased output current or in series for increased output voltage. With master/slave operation, power supplies operate at near equal voltage and current.
PQA SERIES power supplies can operate as a voltage source or current source depending on the control settings and load conditions. If the power supply is operating as a voltage source and the load increases to a point beyond the current command setting, the power supply automatically crosses over to current mode control and operates as a current source at that setting.

Remote Interface Software is included to provide sophisticated computer control. This software provides a virtual control panel to emulate the power supply's front panel, a command panel to send and monitor SCPI commands, a register panel to monitor registers, and a calibration panel to provide easy access to calibration digital potentiometers.

PQA SERIES power supplies have extensive diagnostic functions -- all of which when activated take command to shut down the system. Diagnostic functions include phase loss, excessive thermal conditions, over voltage trip, over current trip, fuse clearing, and program line. Program line monitors externally applied analog set point signals to insure they are within the specified range. Upon a diagnostic fault condition, main power is disconnected and the diagnostic condition is latched into memory. Pressing the clear key clears the memory. All diagnostic functions can be monitored through a rear connector. Furthermore, control functions can also be set through the rear connector to allow simultaneous control of one or more PQA SERIES units.

PQA SERIES supplies have three levels of over voltage/ current protection: shutdown of controlling insulated gate bipolar transistors (IGBT's), disconnect of main power, and input fuses. After an over voltage/current trip condition, the supply must be reset.

PQA SERIES have push button start/stop controls. These controls are tied to a mechanical contactor which operates with the electronic switches to break the ac mains when stop is commanded. Unlike competing products, an off means both an electrical and mechanical break in the power circuit - not a break in an electronic switch. Safety comes first at Magna-Power Electronics.

$\begin{array}{ll}\text { MAGNA-POWER } & \begin{array}{l}\text { 81 Fulton Street, Boonton, NJ 07005 } \\ \text { (973) 263-0017 FAX: (973) 263-1928 } \\ \text { E-mail: sales@magna-power.com } \\ \text { http://www.magna-power.com }\end{array} \\ \text { ELECTRONICS, INC. } & \end{array}$




\section{PQA SERIES \\ HIGH-EFFICIENCY OPERATION! OUTLINE DRAWINGS AND FRONT PANEL INTERFACE}
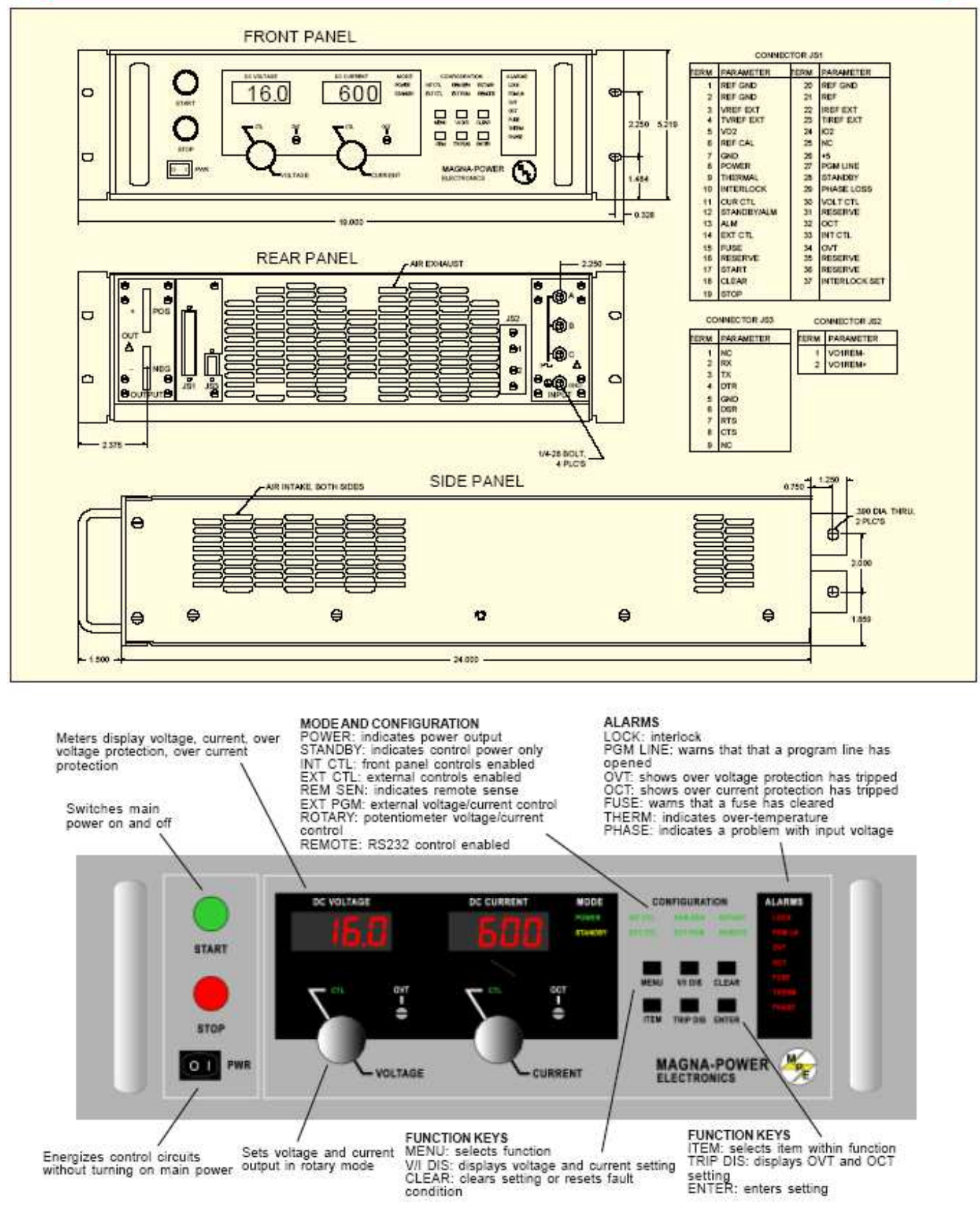


\section{VITA}

Prabha Ramchandra Acharya received her Bachelor of Engineering degree from College of Engineering, Pune University, India in August 1999. She worked as a Software Engineer at Infosys Technologies Limited, Bangalore, India from September 1999 till December 2001. She joined the master's program in electrical engineering at Texas A\&M University in January 2002 and received her master's degree in August 2004. Her research interests include embedded control, fuel cell modeling and simulation.

She can be reached by email at prabha_acharya@yahoo.com. Her address is D-53 Anant Condominiums, Kothari Blocks, Bibvewadi, Pune 411037, India. 